\title{
Between Choice and Sacrifice: Constructions of Community Consent in Reactive Air Pollution Regulation
}

\author{
Noga Morag Levine
}

\begin{abstract}
The author examines the images of community that lie behind the Environmental Protection Agency's decision not to extend proactive, uniform regulation of the Clean Air Act to the problem of local industrial odor. Under this decision, the regulation of such odors remains dependent on complaints and local initiatives rather than on proactive governmental intervention. The legitimacy and economic logic of the reactive structures the agency endorsed rely on two assumptions: (1) industrial odors are an aesthetic annoyance rather than a toxic threat; and (2) local environmental conditions reflect conscious decisionmaking by homogenous local communities as to trade-offs, and preferences for environmental quality will differ among these communities. The author uses three case studies to cast doubt on the validity of these assumptions; they demonstrate in particular the mythical character of the "community" posited by the EPA as a foundation for viable reactive enforcement. Indeed, to trigger enforcement, it has been necessary to undertake heroic organizational efforts and to create novel forms of social groupings hardly characterizable as "communities."
\end{abstract}

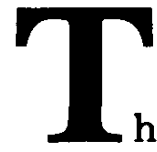

he 1970 Clean Air Act (CAA) was a central element in a wide ranging statutory "rights revolution" (Sunstein 1990) directed at the vestiges of common law ordering that had survived the New Deal, particularly in the areas of environmental, health and safety, and consumer policy. Unlike the common law regime it sought to replace, the CAA advanced a proactive and uniform vision of air quality regulation and substituted national criteria for local community standards. The vast regulatory program implemented under the CAA resulted in reductions in the level of

Research for this article was supported by the National Science Foundation Grant for Improving Doctoral Dissertation Research (No. SBR-9310535) and the University of California Chancelor's Dissertation-Year award. This article could not have been written without the cooperation and help extended to me by members of the citizen groups and staff at the air pollution agencies I studied. I am also grateful for many helpful comments from Cary Coglianese, John Dwyer, Malcolm Feeley, Robert Post, and Martin Shapiro. For constructive and detailed responses to several recent drafts, special thanks are due to Robert Kagan, Michael Lipsett, Elizabeth Mertz, and most of all Jonathan Levine. Remaining errors are of course my own. Earlier versions were presented in the 1992 and 1994 meetings of the Law and Society Association. Address correspondence to Noga Morag Levine, Program in Jurisprudence and Social Policy, University of California, Berkeley CA, 94720.

Law \& Society Review, Volume 28, Number 5 (1994)

(c) 1994 by The Law and Society Association. All rights reserved. 
some prevalent pollutants, most notably lead, particulates, and carbon monoxide (Bryner 1993). But it has had significantly less success in the control of local concentrations of potentially toxic air contaminants (e.g., Graham 1985; Dwyer 1990; Robertson \& Vanderver 1992). For those who breathe and smell such localized industrial fumes, regulatory interventions continue to depend predominantly on effective mobilization of common law-inspired administrative mandates. Under these structures, enforcement is reactive, burdens of proof are carried by complainants and plaintiffs, and judicial and administrative responses are driven by a search for violation of pertinent community air quality norms.

In this article I examine the reasons why the regulation of localized air pollution continues to be both reactive and subject to decentralized standard setting and decisionmaking. The comparatively deferential regulation of localized emissions, as contrasted with the proactive regulation of a few common pollutants, reflects underlying assumptions about the nature of the harm imposed by sources of local pollution and the character of the communities surrounding them. The neutral regulatory stance of reactive air pollution regimes is justified by defining as aesthetic those interferences caused by localized emissions. The presumption that local air pollution derives from voluntary trade-offs between economic and environmental values and is thus unlikely to result in frequent protest is central to the logic of reactive air pollution structures. Where health concerns and multiple complaints nonetheless materialize, agencies face contradictions grounded in competing commitments to both responsive government and the status quo.

I argue that reactive air pollution structures strive to avoid this dilemma by distinguishing the sentiments underlying pollution grievances from those presumably shared by relevant communities. These communities, however, are hypothetical constructs with little relationship to the actual values and choices of pollution-affected locales. Through analysis of three local air pollution disputes, I demonstrate that contrary to aesthetic formulations of the problem, local pollution is perceived as a toxic threat. Further, in opposition to presumptions of reciprocity, industry's neighbors often see themselves as uncompensated victims. In my concluding section, I suggest that discrepancies between the images guiding reactive air pollution regulation and the actual choices local communities increasingly articulate threaten to undermine both the rationale and the legitimacy of reactive environmental regimes.

In response to long-present pressures for the control of industrial odors, Congress included in section 403 of the 1977 Clean Air Act Amendments a specific directive requiring the Environmental Protection Agency (EPA) to evaluate options for na- 
tional regulation of odor pollution. The EPA responded to this mandate in a 1980 report that explicitly rejected proactive federal odor control measures. The decision was justified both by the insensitivity of uniform standards to variations in "community sensibilities and preferences" (U.S. Environmental Protection Agency 1980:59) and the utilitarian benefits that common law nuisance actions offer in this context. In accordance with the rationale of voluntary intercommunity air quality diversity, odor regulation has since remained the sole province of state, regional, and local government. Disputes triggered by the aesthetic affront and toxicological worry industrial odors cause are common throughout the country (Shusterman 1992). They involve a range of facilities, including chemical and plastic manufacturers, foundries, pulp mills, refineries, sewage treatment plants, and agricultural operations (e.g., Barger 1993; Hubert 1993; Laxson 1993; Lee 1993; Manning 1993; Boatwright 1992; Rollenhagen 1994).

The EPA report did not offer an explanation, beyond the subjectivity of olfactory tastes, for its presumption of variation "in community tolerances or odor annoyance levels" (U.S. Environmental Protection Agency 1980:5). But the expectation that many communities would fail to mobilize against industrial pollution was central to the economic logic of the reactive odor policies the EPA endorsed. The industrial and administrative cost savings the EPA associated with common law-based pollution regulation would quickly disappear under conditions of frequent and effective demands for odor relief. Nuisance-based pollution interventions can introduce significant uncertainty into the regulatory expectations of industrial actors. They require expensive retrofitting, more easily and cheaply done in initial construction, and can trigger significant economic disruptions by imposing on some firms abatement costs their competitors avoid. Moreover, the evidentiary burdens that nuisance structures impose on plaintiffs are likely to consume significant administrative resources where air pollution enforcement demands are frequent.

In making the decision to reject proactive odor pollution control, the EPA had before it distinct evidence pointing to correlations between sociodemographic status and the voicing of pollution and other environmental complaints (Copley International Corporation (“CIC") 1970; Lindvall \& Radford 1973; National Research Council 1979). There appeared to be significant basis for the expectation that local mobilization would fail to materialize in many odor-affected locales. Nevertheless, the efficiency gains the EPA expected from nuisance regulation were not solely a function of presumptions of quiescence. As indicated before, the EPA report was itself the product of persistent public concerns and political pressures for odor interventions. The EPA thus had every reason to anticipate frequent odor complaints 
and widespread demands for expensive post hoc controls. If the EPA nevertheless expected reactive odor regulation to yield economic benefits, it was because it assumed that such local mobilization and complaints will only rarely result in abatement measures. This expectation was explicitly acknowledged by the 1980 EPA report in a footnote that all but conceded the futility of most nuisance claims:

Under the most widely recognized view, an odor problem must cause substantial annoyance to qualify as a nuisance. Unusually sensitive individuals are at a distinct disadvantage since annoyance is judged on the basis of the ordinary person living in that locality. Technical legal defenses and burdensome evidentiary problems also detract from the usefulness of nuisance actions and in most cases courts will not issue prohibitory injunctions even if the plaintiff prevails on the merits of his claim. (P. 14 n.*)

The relationship between social structure, choice, and power in local community life has long been a subject of intense debate in American political theory. Much of this debate has centered on the effectiveness of transformations between social problems and local political demands. Whereas adherents of pluralist theories have usually argued in support of the capacity of diverse groups and objectives to influence patterns of local political action (Dahl 1961), their opponents have disputed this assessment along three central lines of argument. The first, primarily associated with Olson (1971), cites collective action impediments to the organization of interests. The second, initially advanced by Bachrach and Baratz (1962), focuses on the place of issue suppression in understandings of political power. ${ }^{1}$ The third argues that political wants may themselves be the product of covert controls influencing conceptions of alternatives and constricting the range of choices considered (Lukes 1974).

Sociolegal scholars have followed a parallel line of inquiry in empirical investigations of a variety of reactive enforcement and allocation structures and have likewise questioned the fit between problems and complaints. While some observers see complaints as a "tip of an iceberg" of a universe of unarticulated and unremediated injuries (Best \& Andreasen 1977:701; Nader \& Shugart 1980), others warn against enforcement distortions caused by "trivial claims" (Bardach \& Kagan 1982:166). Differences in organizational structures appear to play a determining

1 In answer to the call for empirical consideration of nonissues, Crenson (1971) investigated variations in air quality policies within similarly polluted locales and attributed some of the differences he observed to the impact of industrial influence on the suppression of pollution abatement demands. Pluralists such as Polsby (1980:216-17) answered this line of criticism by suggesting that preferences, rather than power, may be at the root of local environmental differences and by positing the possibility of communities united both in their pursuit of economic benefits and in their consent to environmental burdens. 
role both in the frequency of complaints and the rigorousness of complaint-triggered enforcement (Kagan 1994). Where complainants are organized through, for example, labor unions (Bardach \& Kagan 1982; Scholz \& Wei 1986) or trade associations (Hawkins 1984), they can have important impact on the enforcement priorities of an agency. But where such organizational support is missing, researchers have pointed to the silencing impact of socio-cognitive obstacles to problem perception (Felstiner et al. 1980-81), internalized expectations of defeat (Bumiller 1988), entrenched anti-voicing norms (Best \& Andreasen 1977), and negative incentives grounded in inaccessible, complex, or even hostile response mechanisms (Nader 1980a; Crowe 1978). Much of this work has thus lent support to Mayhew's (1968) early observation, in the context of citizen-initiated antidiscrimination policy, of the myriad ways in which reactive law supports and reinforces the status quo.

The central concern of both these political-theoretic and sociolegal debates has been with the conditions under which political and legal challenges to existing distributions do or do not materialize. In contrast, my focus here is on the ways in which redistributive demands, once voiced, are reconciled with continuing allegiance to the status quo. In particular, this study is concerned with the place of legal and institutional conceptions of communities and the norms they share in the marginalization of complainants who dispute the fairness of existing allocations.

Air pollution complaints inevitably challenge presumptions of local environmental tolerance and pit the health and welfare concerns of complainants against the economic interests of industrial plants and their dependents. I argue in this article that in the implementation of such balancing processes, courts and agencies have resorted to artificial constructions of community tolerance despite evidence of local protest. Similar institutional constructions of community-for a variety of purposes-have been observed in both judicial (Yngvesson 1993) and administrative contexts (Reiss 1971; Klockars 1991; Crank 1994). In a study of early efforts at implementing community-based policing, Reiss (1971:209) described calls for local control of central bureaucracies as based on "false assumptions" about population stability and homogeneity. Others viewed such suppositions of moral cohesion less as a mistake than as a legitimating myth (Klockars 1991) serving institutional functions (Crank 1994). I extend this functional perspective to the role of community conceptions in air pollution nuisance regulation and maintain that metaphors of tight-knit industrial communities serve to legitimate regulatory inaction in the face of local air pollution disputes. Invocations of community choice are used within such conflicts as an escape from the moral and political conundrums of imposed sacrifice, because they present outcomes as based in consent rather than 
coercion. Yet because aversions to direct trade-offs between risks to human life and economic benefits are deeply entrenched (Schroeder 1986), the legitimacy of community choice solutions depends, in turn, on a fiction of safe air and definitions of industrial odors as aesthetic annoyances.

Because they challenge presumptions of community tolerance, citizen nuisance suits and pollution complaints confront courts and administrative agencies with hard enforcement choices. Under common law adjudication, this dilemma was often deflected through doctrines of reasonableness, implied consent, and differential thresholds for nuisance in industrial locales (Bone 1986). Current responses to air pollution nuisance disputes are, however, more often administrative rather than judicial. Case studies of the history of three similar foundry pollution disputes reveal differences between the responses offered by courts and agencies to the dilemmas of reactive air pollution control. The case studies illustrate the centrality of administrative tactics designed to avoid explicit balancing or impositions of loss through rituals of complaint handling and strategies of delay. Some citizen groups manage, through a combination of skills, connections, and tenacity, to trigger nuisance interventions under such frameworks. But where the collective action barriers cannot be scaled, administrative inaction in the face of local pollution concentrations is justified through arbitrary presumptions of community choice.

Section I describes the reactive precepts of air pollution regulation under the old regulatory regime, the transformations envisioned by the federal CAA, and the continuing place of common law ordering under current air pollution policy. Section II outlines the background and assumptions behind the EPA's reactive policy decision. Sections III-VI follow the implementation of this policy in the context of judicial and administrative responses to three foundry odor nuisance disputes. The study concludes by linking the dilemmas of odor enforcement to the larger challenges raised by the environmental justice movement and the NIMBY syndrome ${ }^{2}$ regarding the equity and efficiency of community-based environmental allocations.

\section{From the Common Law to the Clean Air Act and Back}

The history of air pollution policy in the United States prior to the 1970s has been characterized in the following terms:

[E]vents not foresight, ushered in each stage of intervention. Intervention tended to consist in curative rather than preventive measures, and was designed to preserve so far as possible

2 The acronym NIMBY stands for "Not In My Back Yard." It has been used in reference to the growing resistance of local communities to unwanted land uses and facilities, ranging from toxic waste sites to prisons (Brion 1991). 
the prevailing social patterns-whether of business practice, citizen behavior, or the distribution of authority among local, state, and federal governments. (Krier \& Ursin 1977:11)

The placement of "burdens of inertia and uncertainty" on "those who sought change in the status quo" was central to the workings of this reactive regime (ibid.).

The primary framework for the adjudication of disputes triggered by the smoke, soot, and odors of industrial emissions was private nuisance tort doctrines prohibiting unreasonable interferences with the enjoyment of property (Juergensmeyer 1967; Laitos 1975). Because of the entanglement of property enjoyment protections with competing rights to gainful use of property, applicable doctrines have long been marked by strains between the rights of plaintiffs and defendants and between corrective justice and utilitarian principles (Epstein 1979; Bone 1986; Rodgers 1986; Lewin 1990). These tensions were particularly pronounced where individual litigants sought injunctive relief from the pollution created by large industrial processes. These requests were often refused. But judges differed fundamentally in the doctrinal approaches they employed at such junctures. Under one approach injunctive relief was denied, despite recognition of injury, through "balance of equities" tests and explicit understandings of pollution as an evil justified by a greater good. In contrast, other courts avoided the explicit sacrifice inherent to such balancing through reasonableness standards and numerous doctrinal mechanisms aimed at distinguishing sensitivities implicitly underlying nuisance claims from relevant local standards (Kurtz 1976; Ellickson 1973; Bone 1986; Lewin 1990).

In addition to private nuisance, the common law has long addressed air pollution concerns under the general category of public nuisance torts. A public nuisance is "any unreasonable interference with rights common to all members of community in general and encompasses public morals, health, safety, peace, or convenience" (Black 1990:1230). Public nuisance structures straddle the boundaries between private and public law. They protect collective interests but follow a reactive logic. Interventions depend on proof of annoyance or damage, and complaints serve important evidentiary and legitimating functions. The hybrid nature of public nuisance facilitated transitions into proactive approaches to pollution control. But in the absence of clear evidence linking pollution with disease, the burdens of proof that public nuisance, like its private counterpart, imposed on plaintiffs and complainants undermined many antipollution initiatives (Pollack 1968; Jones 1975; Grinder 1980).

Antismoke campaigns were undertaken, with some success, by several cities during the first half of the 20th century (Jones 1975). But these improvements were largely the product of technological breakthroughs and the substitution of cleaner energy 
sources for bituminous coal rather than active antipollution enforcement (Grinder 1980). Regulatory interventions were mostly complaint- and crisis-driven, and courts served as "chief allocators" under "a pronounced bias in favor of localism" (Krier \& Ursin 1977:48). A series of catastrophic air pollution episodes during the 1930s, 1940s, and 1950s, coupled with progress in scientific understandings of air pollution hazards, finally transformed problem definitions and governing paradigms in this area (Jones 1975; Krier \& Ursin 1977). Federal regulation began with a series of incremental legislative steps enacted between 1955 and 1967. But it was only with the 1970 Clean Air Act (CAA) that federal air pollution controls were unambiguously asserted and a new regulatory model emerged.

Although the 1970 CAA did not explicitly articulate a right to clean air, its logic and mission were strongly suggestive of such a right. In a move analogous to constitutional rejections of individual and community autonomy in matters of civil rights, the CAA advanced a national, rather than a local, vision of acceptable air quality. Its regulatory ideal was one of proactive, uniform enforcement, and its promise was of safe air to all, irrespective of personal sensitivities, place of residence, or cost (Schroeder 1983).

Scientific optimism and trust in the capacity of unambiguous regulatory incentives to induce technological alternatives to massive environmental and economic losses partially account for the absolutist tenor of the CAA (La Pierre 1977; Krier \& Gillette 1985). But hopes for such innovation were contingent on credible threats of plant closure and willingness to incur the political costs associated with such measures. The hard choices implicit to technology forcing were, however, delegated to the newly created and politically weak EPA (Schoenbrod 1983; Yale Law Journal 1979). And it was there that the CAA's multiple opportunities for silent balancing (Schoenbrod 1983:750) rather than its "aspirational" (Henderson \& Pearson 1978) pronouncements determined the limits of federal air pollution enforcement. The result was a system of de facto compromises and delays framed by a "policy fiction" of unbending controls and equal air quality goals (Eads 1985:229).

As indicated before, the EPA has had considerable success in the reduction of certain prevalent pollutants. ${ }^{3}$ But the regulatory

3 The bulk of the EPA's air pollution control efforts have centered on regional attaintment of National Ambient Air Quality Standards (NAAQS) governing six prevalent, multiple-source pollutants. The six original criteria pollutants were particulates, sulfur dioxide, carbon monoxide, ozone, nitrogen oxide, and hydrocarbons. The EPA added lead to the list in 1977. The hydrocarbon standard was deleted in 1978 as unnecessary, because hydrocarbons are a major component of ozone and are regulated under that standard (Reitze 1991). Emission trends recorded by the EPA over the past two decades reveal significant reduction in levels of lead, carbon monoxide and particulates. Emissions of volatile organic compounds (VOCs) have shown little decline throughout the 1980s (Bryner 1993). 
program it implemented paid little attention to intraregional variations in local air quality and offered limited protection for the often poor and minority populations living in the vicinity of uncontrolled sources of hazardous emissions (Lazarus 1993). Under section 112 of the 1970 CAA, particularly hazardous air contaminants were to be subject to emission standards allowing for "ample margins of safety." But the attempt, despite doubts regarding the existence of safe pollution exposure thresholds, to "outlaw death from air pollution" (Schoenbrod 1983:747) ultimately became a formula for regulatory paralysis (Graham 1985; Goldberg 1988; Dwyer 1990; Robertson \& Vanderver 1992). Between 1970 and 1990 the EPA regulated only seven out of hundreds of potentially toxic air contaminants. ${ }^{4}$

Recognition of this regulatory failure prompted a fundamental overhaul of federal hazardous air pollution mandates in the 1990 Clean Air Act Amendments. Under the revised law, new and old major sources of 189 specified hazardous pollutants are to be subject to Maximum Achievable Control Technology standards (MACT). Other mechanisms are to be applied to smallerarea sources of toxic air contaminants and to some of the residual emissions remaining after the imposition of MACT standards. Unlike its predecessor, the current federal air toxics control program does not promise to eliminate air pollution health risks (Chard 1991). But the more modest goals of the new program justify hope for significant improvement in present levels of airborne toxics exposure. ${ }^{5}$ Although neighbors of currently uncontrolled sources of potentially hazardous pollutants are often unaware of pollution risks in their environment, when industrial pollutants can be detected as odorous fumes, concerns about toxicity often follow. ${ }^{6}$ As indicated earlier, odors of this sort remain subject to common law nuisance, rather than to federal proactive regulation, under a rationale of diverse community trade-offs and sensibilities. The background to the EPA's decision in this context and the reasoning behind it are discussed in greater detail in the following section.

4 They are arsenic, asbestos, benzene, beryllium, mercury, radionuclides and vinyl chloride (Robertson \& Vanderver 1992:201).

5 In recent congressional testimony a senior EPA official conceded the inadequacy of current air quality controls and stated: "Far too many people are exposed to air toxics from large and small stationery sources." Prepared Statement of Mary Nichols, Assistant Administrator for Air \& Radiation, U.S. Environmental Protection Agency, before Subcommittee on Oversight of Government Management, Committee on Governmental Affairs, U.S. Senate, in Federal Document Clearing House, 25 July 1994.

6 The presence of odorous emissions per se does not constitute evidence of exposure to air toxics. Numerous potent odorants can be detected at levels far lower than their known toxicological thresholds. Others are not associated with any long-term risks, and some air contaminants, such as carbon monoxide, are both odorless and hazardous. 


\section{Dilemmas and Options in the Control of Odors}

Growing public attention to air pollution problems during the postwar era brought new pressures for abatement of previously uncontrolled gaseous emissions and the odors they caused. During the 1950s odors were the target of regulatory programs initiated by a number of local and state air pollution agencies (Edelen \& Clark 1951; Gruber 1957; Stern 1957). During the 1960 s interstate odor disputes provided the occasion for some of the earliest federal air pollution control interventions under provisions established in the 1963 Clean Air Act (Nelson 1967). Following the enactment of the 1967 Air Quality Act, the National Air Pollution Control Association engaged Copley International Corporation (CIC) to perform a comprehensive study directed at assessment of the prevalence of odor problems across the United States, the impact of odors on particular communities, and the state of regulatory enforcement (CIC 1970, 1971, 1973). The CIC study estimated that almost five million American are significantly bothered by odors and pointed both to gaps between problem perception and complaints and correlations between sociodemographic levels and air pollution awareness (CIC 1970: 203-5). Public nuisance structures were identified, through a survey of regulatory enforcement practices, as the primary administrative mandates in this area. Interviews conducted with agency representatives in seven metropolitan areas did not reveal any instance in which odor pollution violators were subject to substantial fines or judicial penalties. The CIC study's conclusion regarding the state of regulatory action in this area was that "to date, the tools and devices available to enforcement agencies to deal with odor problems have been virtually nil" (ibid., p. 206). A model odor control ordinance developed in conjunction with the study proposed the use of public opinion surveys, rather than citizen complaints, in regulatory assessments of local odor problems (CIC 1973:17).

The EPA did not adopt the model ordinance and failed to implement any other odor-directed measures under the 1970 CAA. This failure, coupled with continuing public concern with odor pollution problems, resulted in the earlier mentioned congressional directive to the EPA under the 1977 CAA. Two studies were written in compliance with this mandate. The first was commissioned by the EPA from the National Research Council (NRC 1979). The second was the internal EPA report cited earlier in this article (U.S. Environmental Protection Agency 1980). The NRC study included a comprehensive analysis of health and welfare effects of odor, available measurement and abatement technologies, and alternative regulatory approaches to the problem. The NRC report described a number of successful odor control technologies but pointed to important economic impediments to 
their implementation. Because of the low concentrations in which some odorants can be detected, the NRC report noted that "the only sure way to alleviate complaints of malodors downwind of a source is to preclude detection at all. . . . This usually requires control at the source with an efficiency of 95-100\%, which is far greater than the efficiency needed for most gaseous emission" (NRC 1979:179).

The costs associated with comprehensive odor controls are crucial to an understanding of the EPA's subsequent rejection of uniform federal odor control policies. If set at levels sufficient to eliminate most industrial odors, uniform odor standards could dramatically increase pollution control expenditures in many industries. Cheaper and less comprehensive odor abatement mandates might provide incremental improvements in local air quality but would most likely fail to eliminate offensive odors and might stir discontent among residents faced with the knowledge that no further relief is in sight. By focusing on community annoyance rather than odor detection, nuisance approaches bypass the dilemmas inherent to uniform odor controls. While they hold out the possibility of complete abatement, they spare most polluting firms major pollution control expenses by conditioning interventions on citizen proof of violated communal norms.

The NRC report recommended against the establishment of federal ambient air quality or emission standards but did not explicitly justify this recommendation in economic efficiency terms. Instead the report's executive summary emphasized obstacles created by variability in olfactory sensitivity, and argued that "because reactions to odor depend heavily on local values and individual aesthetic judgements; national standard-setting will be very difficult" (NRC 1979:7). Crucial to this recommendation and the aesthetic problem definition it invoked was the assumption that odorous emissions do not constitute a toxicological threat. In a section devoted to the public health aspects of odor pollution, the NRC study stated: "[T] oxic odorous substances in the atmosphere are automatically subject to standard-setting under the Clean Air Act of 1970 and its amendments, and reduction of their presence to below toxic thresholds is mandatory" (NRC 1979:64). Little progress under the EPA's air toxics control program had taken place by 1979 , but the problems encountered in this sphere were not acknowledged by the NRC report.

The EPA's own report referred to the state of air toxics control only to reject the use of emission standards under section 112 of the CAA in the control of odors. The report stated: "To date, EPA has used Section 112 sparingly, reserving it for the regulation of extremely dangerous pollutants such as mercury, asbestos, beryllium and vinyl chloride. Given the present uncertainty regarding the public health effects of odors, it seems quite doubtful that EPA could promulgate a defensible hazardous 
emission standard for the control of specific odorant or for odors generally" (U.S. Environmental Protection Agency 1980:19). The EPA never acknowledged a possible connection between olfactory and toxicological concerns and adhered to strictly aesthetic problem definition of odor intrusions. ${ }^{7}$ This formulation was crucial both to the legitimacy and the outcome of the balancing opportunities the EPA attributed to nuisance structures:

Despite all of its substantive, procedural and evidentiary shortcomings, the nuisance approach is the only odor-regulation strategy now in use that is tied directly to the basic criterion of an unreasonable interference with public or private rights. As in other areas of nuisance law, odor nuisance disputes are resolved on the basis of lay testimony concerning the reasonableness of the defendant's behavior. The level of private or public annoyance is balanced against the defendant's interests in continuing to operate. Numerically based odor control approaches (ambient and source) lack this important feature. This is their basic shortcoming. (Ibid., pp. 14-15)

The EPA never explained how such balancing processes are carried out or what impact community standards have on their implementation. But as suggested earlier, the expectation that complaints would only rarely yield interventions was central to the economic logic of the EPA's nuisance policy. The obstacles that common law judges have long placed before nuisance litigants were explicitly acknowledged by the report (ibid., p. 14). So was the fact that "while most jurisdictions experience many odor problems, few rank them as one of their top agency priorities" (p. 12). The EPA did not, however, link these judicial and administrative impediments to the utilitarian benefits it attributed to nuisance law. Neither did it address the tension between community choice rationales and the difficulties encountered by those who pursue nuisance claims. These tensions are at the heart of the regulatory regime endorsed by the EPA in the regulation of odorous fumes. Their negotiation is the focus of the following analysis of judicial and administrative responses to pollution disputes and complaints.

\section{Consent and Community in Common Law Nuisance Adjudication}

The common law's traditional deference to community standards and local choice has long played a pivotal role in blunting the coercive impact of the utilitarian calculus. Air pollution

7 In 1992 the EPA issued a report specifying odor thresholds for hazardous air pollutants listed in the 1990 CAA (U.S. Environmental Protection Agency 1992). The report acknowledged that under certain circumstances odor perception may be indicative of toxicological risk. The EPA report was not, however, indicative of a shift in the EPA's decision not to regulate odors. Rather, the report was primarily directed at the state and local agencies that respond to the toxic exposure concerns triggered by odors. 
plaintiffs invariably disputed presumptions of fit between local conditions and standards. In the face of such challenges, courts often used arguments directed at distinguishing governing environmental standards from those suggested by nuisance plaintiffs. Nuisance thresholds in industrial neighborhoods were differentiated from those applicable to more bucolic locales; residence in polluted areas was constructed as implied consent and complainants were cast as hypersensitive and unrepresentative members of a local population presumably more tolerant of "trifling inconveniences" in its environment (Bone 1986).

All these arguments were invoked in a 1935 Pennsylvania opinion responding to complaints against the "noxious effects of the smoke dust and odors" emanating from burning piles of mine waste (Versailles Borough v. McKeesport Coal $\mathcal{E}$ Coke Co. 1935). The court justified the losses suffered by the plaintiffs who lived in the vicinity of the mine in the following interpretation of the choices made by local residents: "inhabitants of this district were cognizant of the industrialization of the community when they moved into it. They voluntarily took up abode in this territory, and can scarcely with consistency now be heard to voice a protest about the smokey atmosphere. One who voluntarily goes to war should not complain about cannon smoke" (p. 384). The judge acknowledged the annoyance produced by the emissions and sympathized with "the violence which is done to the aesthetic unities of the community" (p. 394), but concluded that this annoyance is "trivial in comparison to the positive harm and damage that would be done to the community, were the injunction asked for granted" (p. 383).

Much closer in time to the EPA's rejection of proactive federal industrial odor controls was a decision issued by the Illinois Supreme Court (Wells Mfg. Co. v. Pollution Control Bd. 1978). The opinion sustained an appellate court decision reversing an order of the Illinois Pollution Control Board, which had found the operators of an iron foundry guilty of releasing offensive odors, ordered the implementation of abatement measures, and imposed a $\$ 9,000$ fine on the company. The plant in question, Wells Manufacturing, was located in Skokie, Illinois, within an industrial district adjacent to a number of residential neighborhoods and a large high school. The plant was built in 1947 when the area around it was largely undeveloped. The odors attributed to the plant were the product of emissions produced in the casting process when hot metal polymerizes resins used in the binding of sand and cereal molds. The fumes created by this process contain both formaldehyde and phenol and smell like burning rubber. 
Complaints and local organizational efforts directed at the smoke and odors emitted by Wells date to the mid-1960s. ${ }^{8}$ Since the late 1960s both local and state air pollution control agencies have been involved in numerous actions directed at pollution abatement in the plant. Whereas problems related to particulate emissions were essentially resolved by the early 1970 s, concerns over the foundry's odors and their potential health effects persisted. In 1993 the Illinois Environmental Protection Agency and the environmental group Citizens for a Better Environment filed a consolidated complaint before the Illinois Pollution Control Board alleging a violation of sections 9 (a) and $9(b)$ of the state's Environmental Protection Act. Section 9(a) prohibits the emission of air contaminants which "can cause or tend to cause air pollution in Illinois." Section 9 (b) codifies traditional common law nuisance doctrines by defining air pollution as " $[t]$ he presence in the atmosphere of one or more contaminants in suffcient quantities and of such characteristics and duration as to be injurious to human, plant, or animal life, to health or to property, or to unreasonably interfere with the enjoyment of life or property." Under section 33 (c) of the act, in assessing the reasonableness of air pollution emiśsions the Pollution Control Board is required to consider the character and degree of interference, the social and economic value of the pollution source, the suitability of the pollution source to its area, and the technical practicability and economic reasonableness of abatement.

In response to this complaint the Illinois Pollution Control Board held extensive hearings. Twenty-two local residents, high school faculty members, and city officials testified to various effects of the odor on their lives, including nausea, burning eyes and throats, respiratory difficulties, and nagging fears about long-term toxicity. The board also heard from representatives of three firms engaged in the manufacture of technological devices directed at odor control. They described a number of alternative solutions to the problem, including adsorption through activated carbon, chemical absorption, and oxidation of the gases via exposure to ozone. Wells Manufacturing, for its part, introduced the testimony of an odor consultant who maintained that tests he conducted showed $60-90 \%$ reductions in odorous emissions following an adjustment in the composition of the resins used by the company (Wells Mfg. Co. v. Pollution Control Bd. 1977:339), Wells also presented evidence relating to the social and economic value of its plant and the hardships curtailment of its activity would produce.

The First District Appellate Court overturned the Pollution Control Board's decision because of insufficient consideration of relevant circumstances under section 33 (c) of the Environmen-

8 Resolution issued by the Morton Grove (IL) Board of Trustees, 28 Jan. 1974. 
tal Protestation Act. The court characterized the interference caused by the odor as a "mild discomfort" (p. 339) and emphasized that "both the residents of the area and Niles West High School were well aware of the nature of the area when they moved in" (ibid.). Against these factors the Appellate Court emphasized Wells's significance as a "source of necessary industrial parts and as an employer" (ibid.). Finally, the opinion characterized testimony regarding the availability of technical solutions to the problem as "self serving attempts" by "three competing salesmen who had failed to sell their devices to Wells." The court concluded: "It is clear from the record there is no working model anywhere in existence to completely control the odor from the foundry. . . . Unless and until a more efficient means of cutting the emissions from the plant is found, it is unreasonable to expect Wells to do more" (p. 340).

In sustaining the appellate court decision, the Illinois Supreme Court offered the following formulation of the Pollution Control Board's duties in cases such as this: "The Board must balance the costs and benefits of abatement in an effort to distinguish 'the trifling inconvenience, petty annoyance or minor discomfort' from 'a substantial interference with the enjoyment of life and property' ". (Wells Mfg. Co. v. Pollution Control Bd. 1978: 232, quoting Processing $\mathcal{E}$ Books, Inc. v. Pollution Control Bd. 1976:77). The board's error, argued the Illinois Supreme Court, derived from the excessive weight accorded to the odor's local impact over competing considerations in the balancing process. The court agreed with the lower court's finding that "the residents and school were on notice of the possibility that some annoyances present in heavy-manufacturing areas could affect them, and this fact considerably diminishes the potency of their complaints" (p. 236). The court further argued that the burden of proving the reasonableness and practicability of abatement measures lies with the agency. This burden, the court concluded, has not been met because of differences between the control solutions advocated by each of the three experts whose testimony was presented. A later decision by the Illinois EPA and Pollution Control Board to reject Wells's permit renewal request because of its odorous emissions was overturned on appeal on technical grounds (Wells Mfg. Co. v. EPA 1990).

In contrast to formal rationales of community choice, the decisions in both Wells and Versailles placed little emphasis on the actual norms and sensibilities of the populations living in the vicinity of industrial sources. The losses suffered by neighbors were diminished through trivialization of the harm suffered and justified through presumptions of consent. Against the backdrop of repeated testimony concerning health effects and toxicological worry, both courts adhered to aesthetic definitions of the problem of industrial odors. Similarly, neither the residential choices 
available to mine workers during the 1930s nor the apparent ignorance of suburban homebuyers regarding the potential impact of uncontrolled industry was deemed relevant to governing assumptions of consent.

Not all nuisance decisions followed the pattern described above. Strains of anti-utilitarian, rights-based reasoning have long existed in the doctrines of some courts and jurisdictions (Rodgers 1986). The Wells decision itself included two strong dissenting opinions. Nevertheless, as the EPA report has itself recognized, prevailing patterns in air pollution adjudication accord with the majority's position in Wells.

Public nuisance adjudication is unusual, however, in today's administrative environment. The EPA report noted this phenomenon and stated that the "vast majority of odor problems are resolved extrajudicially. Only in relatively rare cases of strong community pressure and stiff industry resistance do these matters require adjudicatory resolution" (U.S. Environmental Protection Agency 1980:13). The following case studies are directed at an examination of the manner in which agencies have responded to the dilemmas of reactive air pollution regulation and the ways in which their solutions differ from those developed by judges in common law nuisance actions. ${ }^{9}$ Unlike the filing of lawsuits, which can only be executed with significant effort and expense, the voicing of air pollution complaints is relatively easy. Consequently, air pollution control agencies, much more than courts, are likely to encounter frequent calls for intervention. Yet, perhaps even to a greater extent than courts, agencies of this sort are ill prepared to undertake the redistributive tasks demanded by air pollution complainants. Unlike judges, air pollution administrators must enforce the allocative decisions they make and are subject to direct and explicit political pressures. Moreover, although odor complaints are often the prime context in which the general public comes into contact with the agency, odor enforcement is marginal to the central statutory mission of these agencies under the federal CAA. Aggressive odor abatement measures could threaten more urgent administrative priorities by undermining an agency's relationship with regulated entities. On the other hand, failure to respond adequately to air pollution complaints is likely to result in negative publicity and unwanted political attention. The alternative is nondecision, something that agencies, unlike courts, may opt for. The extent to which this option has been pursued, and the role played by administra-

9 The case studies that follow are based on participant observation derived from the author's experience as a regular complainant and participant in the group efforts surrounding the Berkeley case, archival research in each agency investigated, interviews with agency personal and members of the local groups associated with each dispute, and a review of pertinent media accounts. 
tive constructions of local choice in its implementation are at the center of the following sections.

Whereas the texts of judicial opinions are the primary source for the study of adjudicative responses to environmental grievances, evaluations of reactive administrative policies depend on detailed understandings of the regulatory processes that citizen pollution complaints trigger. I have explored the specific criteria agencies employ in definitions of relevant local standards and the nature of the responses air pollution complaints generate. The case studies I report here analyze the general odor enforcement policies of two large air pollution control agencies and follow the implementation of these policies in the context of two foundry emission disputes that are much like the Wells Manufacturing case.

Foundries of this sort were recognized in the NRC (1979) report as sources of potentially significant odorous emissions, but in contrast to the position adopted by the Wells court in 1978, the NRC cited a number of potentially effective technological approaches to the control of foundry odors, among them incineration, catalytic combustion, and wet scrubbing (NRC 1979:317). At present, the installation of any such controls, under the reactive regime retained by the EPA, is contingent on specific findings of local odor violations. Uncontrolled sources of potentially toxic foundry emissions are currently among the processes targeted for abatement under the air toxics control measures of the 1990 CAA (Petriko 1993). The case studies suggest the centrality of toxicity concerns in foundry odor disputes and contrast these concerns with the aesthetic annoyance problem definitions governing the responses of two local agencies. Despite important differences in ultimate outcome and agency approach, the evolution of the two disputes reflects fundamental tensions within reactive air pollution regulation and points to the role that administrative constructions of community and choice serve in the deferment of redistributive measures.

\section{Regulatory Definitions of Nuisance and Community Annoyance: Bay Area Air Quality Management District}

In its 1980 report the EPA singled the nuisance definitions employed by the Bay Area Air Quality Management District (BAAQMD) as "[p]robably, the most clearly drafted and well conceived odor regulation in effect today" (pp. 40). The BAAQMD is the regional air pollution agency in the San Francisco Bay Area. It is the second largest air pollution agency in California and is broadly considered to be well staffed, professional, and effective. California's pollution laws are particularly strict, and environmental awareness in the Bay Area is high. The BAAQMD annually 
logs and investigates thousands of pollution complaints ${ }^{10}$ and considers complaint response to be an important agency priority. Nevertheless, citizens in odor-affected areas often express deep frustration with the agency's policies. The former chairperson of the BAAQMD's independent quasi-judicial hearing board echoed these sentiments at the conclusion of one odor nuisance hearing:

There is a very large number of aspects of the District's approach to odor nuisance cases ... which I simply cannot understand. ... First, I do not understand ... why members of the public dealing with the agency, with respect to odor nuisance complaints, end up so frequently feeling that they, the members of the public, somehow were at fault in failing to figure out how to get the message through to the agency, which presumably is responsive to this kind of public problem. ... The first of it is that there's an awful lot of what appears to me to be a serious lack of responsiveness and aggressiveness on the part of the District staff in these odor nuisance cases. I find it extremely frustrating, extremely disappointing, for an agency that in so many other respects is expert and aggressive. ${ }^{11}$

The reasons behind the regulatory puzzle hinted at by these comments are at the center of the following analysis.

Air pollution nuisances are regulated in California under section 41700 of the Health and Safety Code, which prohibits the release of air contaminants causing injury or nuisance to a considerable number of people or the public. The BAAQMD has interpreted this mandate through two evidentiary procedures. The first, which can be triggered only when a source has been the subject of complaints by at least 10 individuals during a 90 -day period, follows the assumption that odorous air pollution can cause a community annoyance when odorant concentrations in ambient air are at least four times greater than the minimum concentrations at which these odorants can be smelled. Under this premise, air samples collected from the vicinity of suspected odor sources are subjected to fourfold dilution and presented to a panel of three BAAQMD employees. A nuisance violation is established if two of the three panelists detect the odor following its dilution (BAAQMD Regulation 7). Although the BAAQMD has successfully relied on this method to substantiate violations caused by potent odorants such as pulp mill emissions (Shusterman 1992), less intensive odors often cannot be verified after the specified dilutions.

Most odor nuisance violation notices issued by the BAAQMD are the product of a second, exclusively complaint-based eviden-

10 The number of odor complaints received by the BAAQMD has been gradually increasing. Whereas in 1976 the district logged 2,307 complaints of which $65 \%$ were odor related (NRC 1979:474), in 1991 it recorded 7,270 pollution complaints of which 4,842 pertained to odors (BAAQMD records).

11 Comments at Conclusion of Hearing by Hearing Board Member Kenneth A. Manaster, Docket No. 2087, Apco v. Becton-Dickinson, 6 July 1989. 
tiary criterion. Under this criterion, emissions from an industrial facility are considered a public nuisance when complaints from five separate households downwind are confirmed by the district within a 24-hour period (Chaset 1987). While on its face, this formula appears to offer a rather liberal interpretation of section 41700 's reference to a "considerable number of people," the controversies surrounding the BAAQMD's nuisance enforcement practices have largely been the product of the obstacles presented by this "rule of five." The BAAQMD operates a toll-free complaint hot line around the clock and investigates all the complaints it receives. The complaint telephone number is listed in all local phone books, and the district's complaint procedures are explained in its public service publications, but the BAAQMD does not solicit complaints or actively inform residents of polluted locales of its program. Complainants must discover the district on their own, often after fruitless calls to police, fire departments, or the local municipality. When an odor nuisance complaint comes in during regular working hours, an inspector is dispatched to the complainant's location. After-hours complaint investigations are initiated only when there are three or more complaints against the same source. A complaint is confirmed when both inspector and complainant can together smell the odor and the inspector can trace the emissions to a particular source. Complaint response time depends on staffing and the specific availability of inspectors. Although the BAAQMD aims for a response time of 30-45 minutes (Chaset 1987), longer response times are common.

Odors often come and go in unstable and unpredictable patterns. Shifts in wind direction and variations in industrial processes can make odorous emissions difficult to verify at any specific moment. If an inspector and the complainant cannot together smell the odor, the complaint cannot be confirmed, even if the inspector has independently detected the odor. Complaint verification thus depends on the concurrence of the following factors: the continuation of the odor-causing process, stable meteorology, the presence of the complainant when the inspector arrives, and the inspector's ability to trace the odor to a source. Only when all of these coincide during the inspector's visit can a complaint be confirmed. Not surprisingly, most complaints are not confirmed.

Some complainants react with embarrassment at their failure to confirm a complaint, particularly as inspectors may interrupt other duties and often drive considerable distance to investigate complaints. When they fail to confirm, complainants at times feel at fault and act apologetic. Others become hostile, blaming the inspector for his/her delay or for the district's general policies. Many, after a number of such failures, stop complaining. Those who persist become well acquainted with the inspectors who time 
after time visit their house. Although such repeated encounters will in all likelihood yield confirmations, a confirmed complaint will only result in a nuisance violation if four or more additional complaints are confirmed on the same day. ${ }^{12}$ With one relatively minor modification, ${ }^{13}$ the BAAQMD staff has been unwilling to depart from this policy despite the significant enforcement and public relations costs it has exacted.

The BAAQMD justifies its procedural nuisance requirements by the requisites of legal proof, 14 a cautiousness well supported by the results in decisions such as Wells. Nevertheless, evidentiary constraints appear to provide an incomplete explanation for the policy choices made in this context. Demands for face-to-face confirmations ostensibly stem from the need to assure, under the logic of reactive enforcement, that smells detected by inspectors are indeed the ones responsible for complaints. Where multiple potential odor sources are present, questions about the specific identity of odors might arise. In most chronic odor nuisance situations, however, inspectors are amply familiar with the specific odors mentioned and described by complainants and gather little additional information from repeated personal interviews. Likewise, there appears to be little evidentiary justification for the 24-hour cutoff. The district's definition does not allow for the consideration of cumulative complaints on aggregate annoyances and defines nuisance disputes in discrete time-bound terms. Each day's complainants are distinguished from those of the day before, and each morning the counting begins anew. Neither section 47100 nor the doctrinal precepts of public nuisance dictate such an interpretation, and both appear compatible, at least in principle, with methods and criteria that allow for history and context in the assessment of nuisance.

Public nuisance prosecutions àre, as a matter of fact, very rare in the BAAQMD, and citations are most often settled within the agency (Chaset 1987). It is thus the agency, not the courts, that in almost all cases directly faces the dilemmas that have long shaped pollution nuisance adjudication, and it is in terms of

12 While the BAAQMD does not issue a violation notice in the absence of five confirmed complaints, it has been willing, under some circumstances, to bring before its hearing board requests for abatement of odors that did not produce violation notices. Report regarding District Complaint Confirmation and Enforcement Policy Concerning Pacific Steel Casting Company, attachment B, 14 June 1989.

13 That modification relaxes the requirement for five face-to-face confirmations under the following circumstances: the odor problem is ongoing, the complainant has previously been found "reliable," three face-to-face confirmations have already occurred on that day, and no more than an hour has passed between the registration of the complaint and the inspector's visit. BAAQMD Odor Enforcement pamphlet.

14 In response to criticisms of its policy, BAAQMD staff has argued: "We do not believe that we could reasonably expect a court to award civil penalties for any given violation of Health and Safety Code Section 41700 unless the District staff were able to confirm and prove that on the day in question the offending odor affected such a 'considerable number of persons.' " Report Regarding District Complaint Confirmation, 14 June 1989. 
these dilemmas that the "rule of five" can perhaps best be understood. The primary significance of nuisance violations lies not in the fines they can trigger but in the community tolerance suppositions they debunk. Under the logic of reactive air pollution enforcement, the accumulation of nuisance citations provides a clear mandate for intervention. Common law judges evaded such thresholds through multiple doctrinal constructions of local standards and consent. The BAAQMD's fourfold dilution and the requirement of five confirmations in a day serve analogous sifting functions. Yet, unlike common law decisions such as Versailles or Wells, the BAAQMD does not openly justify nuisance distinctions by neighborhood characteristics, residential choice, or definitions of odor as a trivial aesthetic concern. The redistributive implications of its own policy are hidden behind collective action barriers inherent to the conditions specified by its rule of five. Prospects for multiple complaint confirmations rise sharply when neighbors alert one another to the presence of the odor and coordinate complaints. As will be later shown, subsequent abatement action likewise depends on concerted and prolonged local organizational efforts. Thus nuisance interventions by the BAAQMD tend to be allocated only to places where residents can support and sustain intensive mobilization efforts.

Although community mobilization is often crucial to successful negotiation of the five confirmations rule, its legitimacy within structures of reactive regulation is uncertain (Black 1973). In situations of ongoing odor disputes, local residents have, on numerous occasions, used phone trees to encourage complaints and increase their temporal proximity, and the BAAQMD has knowingly issued violation notices based on phone-tree-generated complaints. One such phone tree was created in a neighborhood adjacent to Pacific Steel Casting (PSC), a foundry located at the industrial edge of Berkeley, California. The foundry was accused of emitting odors like those created by the Wells facility. PSC challenged a violation notice issued after it confirmed that complaints were filed by neighbors who used a phone tree to alert others to the presence of the odor. The case came before a local municipal court where the violation notice was dismissed (Bay Area Air Quality Management Dist. v. Pacific Steel Castings Co. 1991). In support of his decision, the judge cited both the absence of sufficient spontaneity in coordinated complaint mechanisms and the nature of the locale in question. The judge described the impact of the phone tree in the following terms:

The complaint process has been skewed by the arborial [sic] complainants. In order to validate the constitutionality of the statute authorizing these penalties, one must have confidence in the spontaneity and self generation of the complaints themselves. If it is not spontaneous and self-generating and of a nature in and of itself to impel the "victim" to complain, it is prob- 
ably not a nuisance. A true "nuisance" must be presumed to be so offensive as to be recognizable as such by ordinary reasonable people in substantially large portions of the community. (P. 7)

As to the relationship between locale characteristics and pollution nuisance thresholds, the judge argued:

In this regard the nature of the surrounding area must be considered, for what is a nuisance in one area may not be a nuisance in another. . . . People who move into an industrial area must adjust their sensibilities to the realities of commerce. They live there cheaper than elsewhere because of the area's shortcomings, and should not expect the refinements of the lakeside countryclub. It is clear that from the nature of the area in which the defendant's business is located, that the odors which it occasionally emits are not such as to constitute a public nuisance in that area. (Pp. 7-8)

The BAAQMD did not appeal the decision. The foundry was in the midst of comprehensive odor reduction measures expected to resolve the long dispute, and an appeal would have cut into other administrative priorities. But perhaps more significantly, successful appeal of the case would have depended on the agency's willingness to indict both its nuisance definition policies and its actions in the decade-long dispute preceding the phonetree decision.

\section{Foundry Odors and Nuisance Regulation: Berkeley, California}

Pacific Steel Casting melts and casts scrap metal in three adjoining facilities built in 1934, 1975, and 1981. During the 1980 s the company employed between 300 and 550 individuals. ${ }^{15}$ The foundry's immediate neighbors are an ink manufacturer, a cement company, and a tire repair shop, but the nearest residential neighbors are only a few blocks away. The factory's surroundings, a checkerboard of industrial buildings and older homes, has been gradually transforming as new commercial developments moved in, and some of the factories shut down. About a half-mile east of PSC, across the main thoroughfare of San Pablo Avenue, are the middle-class residential neighborhoods of Berkeley and Albany. To the northeast is a large married-student housing complex operated by the University of California.

Odor complaints against PSC began to reach the BAAQMD in the mid-1970s ${ }^{16}$ and continued throughout the 1980s. Complainants described the odor as "bakelite," "burning plastic," "metal-

15 Air Pollution Contral Officer v. Pacific Steel Casting Co., Accusation of Violation of California Health \& Safety Code sec. 41700, and application for order for abatement, Docket No. 832, 22 March 1982.

16 Case Summary, Pacific Steel Casting Co., 25 Feb. 1982 (BAAQMD files). 
lic," "toxic," or referred to it by the unofficial code name "burning pot handle." 17 The odor varied in its intensity, tended to come in waves of differing durations, and affected an area of about $1 \frac{1 / 2}{2}$ square miles. Physical effects attributed to the fumes were eye and throat irritation, headaches, and, most commonly, nausea. Compounds emitted by PSC included ammonia, carbon monoxide, formaldehyde, nitrogen oxides, and phenol, but the emission's downwind concentrations and toxicological impact were never systematically studied. 18

In 1982 a BAAQMD inspector recorded the following complainant testimony:

I hate just having to stay inside all the time, but it's the only way I can stay away from it. I retired 2 years ago and I only live on Social Security. I've lived in this house 35 years and I can't afford to move. I feel trapped. When I went to work, I used to smell it when I left, but I was going to work so I didn't call [BAAQMD]. Now, I don't call [BAAQMD] because I think that it is useless. It knocks me out. It makes me sick. My grandchildren are with me for the past 3 weeks. The oldest has asthma and allergies and I worry that it might be affecting them. ${ }^{19}$

A report submitted by the two area inspectors around that time described the situation in the following terms:

PSC has one of the cleanest foundries in the Bay Area. Unfortunately, the odor from a foundry is distinctive and PSC's odor is traveling two miles and more. Within four blocks of the company, the odor is present daily. In other areas downwind of PSC, the odor is present intermittently, but on some days, the odor may become intensified, lingering for hours. The complainants are universally worried about the toxicity of the odor. ... Complainants have been informed that BAAQMD does not generally regulate toxic chemicals and this fact causes additional consternation. Complainants are frustrated that they are

17 Ibid. and BAAQMD complaint records.

18 In 1990, in response to growing pressures from local citizens, the City of Berkeley required PSC to pay for a limited study, by a local consultant, of the potential health risks of its emissions. The study"s primary conclusions were (1) "[s]ome chemical emissions characteristic of routine casting operations, such as ammonia, formaldehyde, nitrogen dioxide, and phenol, may be present at levels which can be smelled by some persons but pose no health risk"; (2) risks from inhalation of methylene chloride and fluorides could not be judged (Bendix 1990:4). The study's conclusions regarding local levels of exposure were primarily based on an earlier consultant's report to PSC. In response to that report, BAAQMD's own toxicologist has stated: "The sampling conducted are [sic] inadequate to support the conclusions drawn. Three samples were taken; it is inappropriate to base any characterization of chronic exposure on such a limited data base." The toxicologist concluded, however: "There is no evidence to suggest that toxic emissions from PSC represent an imminent threat to public health (Office Memorandum regarding potential health risk from PSC, 24 May 1989, Attachment D in Report of Air Pollution Control Officer "Regarding District Complaint Confirmation and Enforcement Policy Concerning Pacific Casting Company, 14 June 1989).

19 Inspector report for violation notice \#18680, 7/26/1982. The same report included additional statements by other complainants who attributed nausea, headache, and irritated eyes to the odor and expressed concern about its potential long-term health risks. 
forced to breathe an odor whose toxicity has not been analyzed. ${ }^{20}$

When the dispute began, during the early 1980s, air pollution control equipment at PSC was exclusively directed at the capture of smoke and particulates. Gaseous emissions were uncontrolled. Despite the known odor potential of foundries such as PSC's and a history of scattered complaints dating to the mid1970 s, the company was not required to install odor controls in the new plants it opened in 1975 and 1980. The absence of such controls conformed with the reactive, remedial logic of interventions in this area and the relevance of established community sensibilities to proof of nuisance. ${ }^{21}$ The number of odor complaints against PSC increased significantly in the early 1980s, following the opening of PSC's third plant and the beginning of local organizational efforts. ${ }^{22}$ In 1981 a local grassroots group, Neighbors for Clean Air (NCA), was formed. NCA held local meetings, distributed flyers, and contacted local politicians, City of Berkeley administrators, and newspaper reporters. In November of that year, NCA succeeded in confirming seven complaints against PSC on a single day, and the company received its first nuisance violation citation. In a routine inspection conducted shortly before that date, it was discovered that plant No. 2, which had opened in 1975, lacked an operating license. Plant No. 3 was operating at the time on a "startup" basis, and it also did not have a permit to operate. In view of the evident odor problems created by the plants, a report submitted by two BAAQMD inspectors assigned to the area recommended against the granting of operating permits to the new plants, a move that would have forced the company to choose between shutting down or abating the odor. The company responded with the argument that "no one else in the industry controls the odor and no known method for control exists" and that a denial of a permit to plant No. 3 would bankrupt PSC. ${ }^{23}$ The BAAQMD retroactively granted the permits to the company in 1982 but brought an application for abatement action before its hearing board. It was the first step in an almost 10-year-long process.

The hearing board held two public hearings on the matter in the spring of 1982. During those hearings, the board heard repeated, extensive, and angry testimony from neighbors in the

20 BAAQMD Case Summary of Pacific Steel Casting, 25 Feb. 1982.

21 A suggestion made in 1991 by the BAAQMD Advisory Council's Public Health Committee that the district proactively consider potential for odor nuisances in permitting decisions was rejected by the BAAQMD's director of enforcement. The director argued that because the threshold of odor tolerance varies between communities, odor abatement cases "warrant site-specific solutions on a case by case basis." Minutes of BAAQMD Advisory Council-Public Health Committee, 3 Dec. 1991.

22 Between May and December 1981, BAAQMD inspectors confirmed 48 complaints, compared with a total of 13 confirmations in the five preceding years.

23 BAAQMD Case Summary, Pacific Steel Casting Co., 25 Feb. 1982. 
area. Residents testified to smelling the odor for years before they identified its source or heard about the air district. Some complained of headaches and nausea brought on by the odor, and many expressed concerns about the long-term health effects of the emissions and the safety of bearing and raising children in that environment. ${ }^{24}$ PSC expressed surprise at the strength of the opposition it was facing from its long-quiescent neighborhood. It blamed its problems on the environmental sensitivity and political activism of its Berkeley milieu and offered both comparisons with other foundries and the previous scarcity of complaints as evidence that the neighbors and not its operations were to blame.

After making a formal finding of public nuisance, the hearing board instructed PSC in the spring of 1982 to formulate and present before it a comprehensive odor abatement plan. The primary feature of the plan the company developed after repeated delays and five public hearings late in fall 1983 was the elevation of plant No. 2's stack. The plan, which was recommended by an odor expert retained by PSC, was significantly cheaper than a scrubber solution advocated by an earlier consultant and supported by the BAAQMD's staff. It was, however, strongly opposed by NCA who, in growing frustration over the slow pace of progress, hired its own attorney.

The hearing board had similar doubts regarding the efficacy of the stack solution and the sincerity of PSC's efforts. It resented the company's repeated delays and sympathized with NCA's anger. Suspecting that the stack solution would only succeed in buying more time for the foundry, the hearing board decided to change the incentives guiding the company's compliance choices. In February 1983 it issued an unconditional order of abatement which was to go into effect after the stack was installed. If the stack solution succeeded, the company would be in compliance with the terms of the order. If, on the other hand, the solution was ineffective, PSC could be subjected to very high fines and potential shutdown orders. It was the hearing board's ultimate weapon.

The stack was built in March 1983, at a cost of $\$ 282,000$. As the board suspected, it did not reduce the odors. The BAAQMD staff, however, strongly opposed the unconditional order. It expressed concern about the protracted litigation such an order would trigger and repeatedly argued for another negotiated solution. The BAAQMD legal staff refused to defend the hearing board's order against a suit brought by PSC, and the board had to retain its own legal representation. The unconditional order was remanded back to the hearing board, and a negotiated plan

24 Transcripts of Public Hearing testimony before the BAAQMD hearing board, 27 May 1982. 
for the installation of dry scrubbers was ultimately implemented. The scrubbers brought some improvement, but complaints persisted; in the fall of 1984 numerous violation notices were issued.

In October 1984 the hearing board came to Berkeley for a hearing that lasted all day and well into the evening. Fifty area residents expressed their fear and outrage and recounted the interferences the odors were continuing to have in their lives. ${ }^{25}$ Later that fall, in a sharply worded document the board issued another unconditional abatement order, writing:

Although it is indisputable that the elimination of this nuisance never would have been easy, it could have been and should have been accomplished long ago. ... The Hearing Board has been told repeatedly in this case that a solution is "finally" at hand, only later to be told that the experts were mistaken, the data were incomplete, and the problem is different from what the Hearing Board previously was told. ... The burden of this uncertainty has been borne by the citizen neighbors of Respondent during all of this time.... The Company will now bear the burden of the continuing uncertainty it has created. It also will bear the risk of failure. ... It is time for the Company to comply with the law or to bear the consequences of continuing to violate the law. Enough is enough. ${ }^{26}$

Like its predecessor, this order too was opposed by the BAAQMD staff. NCA could not support an attorney throughout the litigation the order would have entailed and, after four years, was eager for quick resolution. In March 1985 the BAAQMD, NCA, and PSC entered a consent decree agreement that centered on the installation of a carbon adsorption system on plant No. 2's two baghouses for a sum of $\$ 806,000 .{ }^{27}$ No pollution controls were implemented under the terms of the agreement in plants No. 1 and No. 3. Although emissions from these plants were the target of some complaints in the early 1980s, most of NCA's membership and the bulk of the complaints came from areas primarily affected by plant No. 2. The unconditional order of abatement issued by the hearing board was acknowledged in the consent decree and remained in effect.

By the end of 1985 the carbon adsorption unit in plant No. 2 was installed and complaints in the area diminished significantly. Although some improvement in air quality appeared to have been achieved by the consent decree, an NCA activist attributed the drop in complaints over the next two years primarily to exhaustion and a hiatus in local organizational activity. After five

25 Air Pollution Control Officer v. Pacific Steel Casting Co., Docket No. 832, Revised \& Consolidated Order for Abatement, p. 41.

26 Unconditional order of abatement, 13 Dec. 1984

27 Internal memorandum from inspections manager to Director of Enforcement regarding district enforcement actions to reduce and/or minimize odors from Pacific Steel Casting, p. 2 (1992). 
years, NCA members were tired, financially extended, and desperate to believe that their efforts had borne some fruit. ${ }^{28}$

Regardless of whether a real improvement occurred in 1986, by 1987 complaints were again being filed. The situation at the time largely resembled the state of affairs in the early 1980s. NCA, despite growing recognition that the problem was not solved, was inactive. Many new residents to the area were not aware of the BAAQMD and did not know where they should complain. ${ }^{29}$ Some who did complain became frustrated by the slow response time and critical attitude of one inspector, who on many occasions had defended the company and its efforts to correct the nuisance. ${ }^{30}$ After one or two attempts at confirmation, many stopped calling. Between 1986 and 1988 only three nuisance violation days occurred.

The number of complaints began to rise in late 1987, primarily because of new organizational initiatives in Albany Village, a University of California family housing complex about a mile northeast and downwind from the plant. Albany Village was primarily affected by emissions from plant No. 1, which had not been addressed by the 1985 consent decree. Village residents filed some complaints with the BAAQMD in the early 1980s, but because of the transiency of the Village population and its isolation from residents in the surrounding neighborhood, local residents had not joined in NCA's efforts during that time. When the Village began organizing in response to the odor in late 1988, local efforts were greatly aided by the neighborhood's high population density, efficient communication channels, and its underlying sense of community.

Between November 1987 and November 1988, 200 complaints were filed against PSC and 50 were confirmed. Nevertheless, because the rule of five was not met on any one day during this period, no violation notices were issued and no abatement action was undertaken. Despite the hearing board's still standing unconditional order, the burden of proof as to the presence of a nuisance was, once again, the neighborhood's. In testimony made before the hearing board in February 1989, the BAAQMD's Senior Assistant District Council offered the following interpretation of the state of the dispute:

Now we are in a gray area. We don't have a public nuisance, but we are very close to a public nuisance situation. If the community is effectively mobilized, as they were in the past, we know we will have a public nuisance next year. We think that they

28 Personal interview, 21 Nov. 1990.

29 In testimony given before the hearing board in March 1989, Berkeley Councilwoman Nancy Skinner testified that her office received many complaints from people who were unaware of what the odor was or what they might do about it.

so Citizen testimony in Hearing on Compliance Status Report, Docket No. 832, 2 Feb. 1989. 
reduced their odors substantially. However, even with that new, better, reduced level of odors, sensitivity changes and the community changes and that is no longer an acceptable level in the community. ${ }^{31}$

In March 1989 a regrouped Neighbors for Clean Air filed an injunctive relief suit against PSC. Two weeks later it was joined by the BAAQMD. In June of that year, the BAAQMD, NCA, PSC, and the local glass molders union (which intervened on behalf of the company) signed a second consent decree. In accordance with this agreement, PSC, in April 1991, 10 years after NCA first organized, installed in plant No. 1 a carbon adsorption system like the one installed at plant No. 2 in 1985.32 Although occasional complaints against PSC are still recorded by the BAAQMD, air quality in the area has, by almost all accounts, greatly improved. ${ }^{33}$

Throughout this long dispute, the City of Berkeley remained largely passive. In an evaluation of PSC's 1974 use permit request for plant No. 2, the secretary of the Berkeley Board of Adjustments stated: "Heavy industry of this type is pretty closely regulated by agencies such as BAAPCD, ${ }^{34}$ and the need for conditional approval, if that should be the decision by the Board, may simply rely on other agency review." 35 Plant No. 3 was similarly supported by a memorandum stating that "[a] tour through plant 2 was nearly convincing that this kind of use does not have the potential to cause detriment as in earlier years, especially given the control by BAAPCD." 36 There is no indication that the City of Berkeley understood the reactive nature of the air district's policies in this area and the significance of the company's emphasis on dust control rather than fume control. But there is also little doubt that the city was extremely interested in industrial development and union employment in an area that "just a few years ago, was blighted by wrecking yards and seemed to have no future" 37 and saw little incentive for strict regulation of the environmental impacts of the proposed project. ${ }^{38}$

31 BAAQMD Hearing Board Transcripts, 2 Feb. 1989.

32 Cost for the design and construction of this unit was about $\$ 1.8$ million. In addition, hoods were constructed above the molding stations in plant No. 2 to direct air to the existing carbon adsorption system and adjustments were made in the plant No. 3 ventilation system (Chan 1992).

33 There were 9 confirmed and 44 unconfirmed complaints in 1992, 1 confirmed and 13 unconfirmed complaints in 1993, and 2 confirmed and 13 unconfirmed complaints for the period between 1 Jan.-15 Jun 1994. BAAQMD Enforcement Division complaint records.

34 The BAAQMD was previously named Bay Area Air Pollution Control District (BAAPCD).

35 Letter from Robert B. Humphrey, Secretary, to members of the Board of Adjustments, 5 July 1974.

36 Memorandum to the Berkeley Board of Adjustments, from Robert B. Humphrey, Secretary, 14 Nov. 1979.

37 Ibid.

38 Ibid. 
The Pacific Steel controversy was, in the context of Berkeley politics, part of a larger conflict over the future of heavy industry in the city's west side. During the 1980s, residential, retail, and office developments began to displace industrial land uses in the area and factory workers became increasingly wary of losing their jobs. PSC's workers perceived the complaints against the company as a threat to their livelihood and as part of a general campaign against industry in the area. A PSC union president offered the following assessment of the community groups fighting the company's emissions:

They're always outside our company, cruising around picking up sand and taking pictures. Then they always go off and call Air Quality Control. They complain constantly. . . . Now they're complaining again, and my company is going to spend a million and a half dollars apiece at two plants ... [b] ut that won't be enough for them. They'll never be satisfied. . . . People say us workers are negative, but there are 300 -plus people working here, and all those jobs could be lost. (Scheinman 1990:29)

NCA repeatedly emphasized that it did not want the company to shut down and expressed its belief in the existence of feasible technological solutions to the problem. This belief was shared by the hearing board, whose unconditional orders were designed to change the company's incentive structure and force it to implement advanced technological solutions rather than stopgap measures. Yet while the board and NCA viewed the possibility of plant closure or relocation as both unlikely and unfortunate, they did not preclude it as a solution of last resort. NCA members derived no direct benefit from PSC and saw themselves as uncompensated victims of its emissions. There were no crosscutting linkages between the company, whose employees mostly lived elsewhere, and the NCA members they met only as complainants. In contrast to the images underpinning air pollution nuisance regulation, there was no single, spatially defined community.

The long-delayed but relatively happy ending of this dispute offers, in retrospect, support for the hearing board's approach. Carbon adsorption solutions were enthusiastically supported by the board in an order it issued in $1984 .{ }^{39}$ Because of its cost, this solution was resisted for years and only incrementally implemented, but it ultimately proved to be both effective and feasible. Under proactive best-available-technology strategies, carbon adsorption or similar technological devices would have been in-

39 Regarding carbon adsorption or thermal oxidation solutions to the odor, the hearing board wrote: "Each of these technologies can reasonably be expected to achieve a control efficiency of approximately $99 \%$. Both are very effective odor control devices, which, if implemented, should eliminate the cause of odor complaints in the West Berkeley community attributable to Pacific Steel Casting Company's operations." Air Pollution Control Officer v. Pacific Steel Casting Co., Docket No. 832, Revised \& Consolidated Order for Abatement, p. 47 (Nov. 1984). 
cluded in the facility's permit condition. Instead, many of the pollutants emitted by PSC remained uncontrolled over more than 10 years of local organization and complaints. For the neighbors who remain embroiled in the foundry dispute described below, even such efforts may not suffice.

\section{Foundry Odors and Nuisance Regulation: Tempe, Arizona}

Capitol Castings is a scrap metal foundry located in Tempe, Arizona. The foundry, which produces mining machinery, utilizes processes similar to those employed by both PSC and Wells. Like its Berkeley and Skokie counterparts, Capitol Castings has been the subject of complaints against "burning rubber" odors attributed to the facility. As was true of PSC during the early 1980s, and continues to be true for Wells, pollution control technology in Capitol Castings is directed at the capture of particulates rather than fumes. The casting process occurs in an area that has a roof but essentially no walls, resulting in significant amounts of fugitive emissions. The company, which in $1993 \mathrm{em}-$ ployed 235 workers, is located on a stretch of unincorporated land surrounded by the city of Tempe. In 1952 when the plant was built, land around it was largely vacant. Today the factory is surrounded by residential neighborhoods, schools, and a large city park built partly as a buffer on land donated by the company. Houses in the neighborhood are modest, rental properties are numerous, and residential turnover is relatively frequent. In recent years, some light industry has begun to move into the area.

Air pollution control authority is vested with the Maricopa County Air Pollution Control Division (MCAPCD). State law specifically mentions odors among the air contaminants constituting air pollution, and public nuisance prohibitions are incorporated into the statutory definition of air pollution by reference to unreasonable interferences "with the comfortable enjoyment of life or property of a substantial part of a community" (Ariz. Rev. Stat. sec. 49-471 (1993)). The MCAPCD registers and claims to investigate air pollution complaints but, despite its mandate under the statute, has been extremely reluctant to issue odor-based violation notices or to initiate enforcement action directed at odors per se. In contrast to the priority assigned by the BAAQMD to complaint response, MCAPCD inspectors are not instructed to answer every complaint and are allowed a "judgment call" as to the urgency of such investigations. ${ }^{40}$

40 Mark Meyer, Maricopa Compliance Supervisor, on repeated citizen allegations that their complaints met with no response, said: "Unfortunately, we don't have manpower available to immediately respond to every complaint. But we attempt to go out and follow up on each group of complaints and determine technically since most complaints involve odors, we attempt to determine where the odor is coming from." Maricopa 
Concerns about Capitol Castings emissions date to the early 1970 s when the first residential development was constructed downwind of the facility (Yozwiak 1993). Intermittent complaints were registered during the 1970s and 1980s, but the MCAPCD, until 1988, undertook no enforcement action. A woman who is currently active on this issue recounted some of what she has heard about earlier complaint attempts:

I have been told from old residents, which are few, that for the past 10 years people have tried on many occasions and have met dead ends and had become discouraged and disgusted with the whole thing. They have lost faith in their city and county governments in dealing with this issue. A few of those people would not even join us with our group, telling us "you are just wasting your time, we've tried it before." 41

In 1988, one local resident began what became an almost five-year-long one-man campaign against the odor. The individual, who moved into the neighborhood in 1987, became aware and concerned about the emissions shortly after moving in. After tracing the odor to Capitol Castings and searching for the responsible regulatory agency, he began a series of complaints to the MCAPCD. He received some phone calls in return but no inspector visits. The complaints, which related to smoke as well as odors, did, however, lead to the issuance of a visible emissions violation notice and a $\$ 300$ fine. The insistent complaints to the MCAPCD and to Maricopa County supervisors led the Air Pollution Division to review Capitol Castings' compliance with applicable particulate and volatile organic compound (VOC) standards. ${ }^{42}$ The MCAPCD concluded that Capitol Castings appeared to be in gross violation of applicable VOC standards and instructed the company in May 1989 to conduct a source test in order to verify the plant's compliance status. ${ }^{43}$ In lieu of conducting this test, Capitol Castings, with MCAPCD approval, moved some of its operations from the Tempe plant to a sister facility.

In April 1989 the local resident who had been complaining for the past year contacted a number of local and state elected officials, including Senator Dennis DeConcini (D-Arizona). Sena-

County Air Pollution Control Hearing-Capitol Castings, Inc. 10 March 1994, Reporter's Transcript of Proceedings, p. 15.

41 Letter to author from Cindy Kominska, 28 April 1994.

42 Particulates are one of the six criteria pollutants subject to NAAQS and regulated by the states through their state implementation plans (SIPs) and regulations. VOCs are organic chemicals (also known as hydrocarbons) which, when mixed with other chemicals in the air, form ozone. Because ozone is one of the criteria pollutants subject to national ambient air quality standards (NAAQS), VOCs as ozone precursors are regulated by the EPA and the states (Bryner 1993).

43 Maricopa County Regulation III, rule 330, sec. 301, limits VOC emissions from core ovens to 4.86 tons per year. MCAPCD estimated in 1989 that Capitol Castings may have emitted as much as 186.55 tons of VOC from its core ovens during 1988. Letter from Daniel W. McGovern, regional administrator, to U.S. Sen. Dennis DeConcini, 28 Sept. 1989. 
tor DeConcini forwarded the letter to the EPA, which identified Capitol Castings, because of its VOC emissions, as a significant violator. ${ }^{44}$ Subsequent monitoring conducted by the MCAPCD between March 1990 and March 1991 showed high levels of total suspended particulates (TSP) at the plant's vicinity, although the extent to which Capitol Castings was responsible for the TSP emissions could not be determined. ${ }^{45}$ The MCAPCD was, however, prompted by this finding to reevaluate the terms of Capitol Castings' permit. Negotiations over the terms of this permit and proper estimates of the plant's emissions stretched for almost two years during which the company continued to operate under an expired permit. ${ }^{46}$

Until 1993, little or no collective neighborhood activity occurred. Intermittent complaints were filed with the MCAPCD as a result of individual discovery and initiative, but complainants were not aware of each other and no concerted action occurred. In the winter of 1993 during a parent-teacher organization meeting at the neighborhood school, one mother raised her concerns about the fumes she had repeatedly noticed in the grounds and sometimes in the classrooms. Other parents who had long had similar worries agreed, and some who knew the local air quality activist urged the PTO to connect with him. Soon afterward a local grassroots group, Clean Air Now (CAN), was formed. In March 1993 CAN held a public meeting at the school that was attended by about 100 residents. ${ }^{47}$ Many of those present spoke of years of concern about emissions they associated with headaches and nausea. Others mentioned respiratory ailments and fears about latent carcinogenic effects. The principal of the school questioned whether Capitol Castings emission were responsible for the fact that $25 \%$ of her students suffered from asthma and allergies. ${ }^{48}$ The meeting and the group's other efforts resulted in television and newspaper reports about the dispute.

44 Letter from Virginia Turner to local citizen, Special Assistant, Office of U.S. Sen. Dennis DeConcini, 20 June 1989.

45 Letter from Daniel W. McGovern, EPA region IX regional administrator, to U.S. Sen. DeConcini, 3 April 1992.

46 Letter from Mark Mayer, Air Quality Engineer II-MCBAPC, to Jill Schlesiger, Office of U.S. Sen. John McCain, 25 Jan. 1994.

47 The meeting was advertised by distributing leaflets door to door. The leaflet informed residents of the MCAPCD's phone number and asked them to relate their story to a local newspaper reporter. It concluded with the motto, "Your presence is a must-The voice of one is weak, the voice of many is strong!"

48 The principal repeated this claim in a formal letter to the MCAPCD hearing board in June 1993. The letter states: "Since becoming principal at Aguilar School nine years ago, I have experienced noticeable heavy fumes in the air on our school campus during school hours. ... Since twenty-five per cent of our student population suffers from asthma and allergies, it is my concern (as well as that of our school nurse) as to how these fumes are affecting our students." Letter from Loretta B. Pacheco, Principal, Aguilar School to Hearing Board, Maricopa County Air Pollution Control Office, 3 June 1993. 
Capitol Castings, like PSC, reacted with surprise to the controversy. In newspaper interviews in March 1993, the plant's senior engineer stated: "we don't have the foggiest idea what the odor is" (Yozwiak 1993), and "We don't think the odors come from this facility. We've investigated the facility on a number of occasions. We don't know where its [sic] coming from" (Hoye 1993). In April 1993 the MCAPCD itself was still unwilling to identify Capitol Castings as the culprit in the odor and issued the following response to a CAN member's inquiry: "The Division has received numerous odor complaints from the area and is continuing to investigate the source. A one-mile survey of the industrial community is being conducted to assist in identifying any possible source of odor." 49

CAN's activities did, however, seem to revive the long-stalled permit proceedings and Capitol Castings was directed, in March 1993, to submit a permit application. The application was formally denied on 30 April 1993, and the MCAPCD issued an order of abatement against the company that was stayed by the MCAPCD's hearing board. The matter finally came for a hearing before the board on 4 June 1993.

The June 1993 public meeting climaxed months of organizational efforts on both sides of the dispute. CAN presented a petition signed by 266 of Capitol Castings neighbors and scores of angry letters detailing symptoms and concerns associated with the odors..$^{50} \mathrm{~A}$ woman who had lived in the area since 1972 testified: "Walk out the back door and you cough, cough and you have to go back in the house."51 Others expressed severe distrust of the air division and the company. Capitol Castings responded with an organizational campaign of its own. ${ }^{52}$ It presented many letters in which its employees recounted their dependence on and loyalty to the company. In one such letter an employee wrote:

I can not begin to tell you what my career and my job at Capitol Castings means to me and my wife. As you know, today's economy is not what it use to be and jobs are not easy to come by. Three years ago I began the nightmare of job searching . . . then I was hired at Capitol Castings in 1992. In September of 1993.

49 Letter from B. J. Atwood, Enforcement Manager, to Cindy Kominska, 16 April

50 The letters were specifically solicited by CAN, which also circulated during that time a questionnaire in which it inquired about residents' health problems and concerns.

51 Maricopa County Air Pollution Control Hearings-Capitol Castings, Inc., 4 June 1993, Reporter's Transcript of Proceedings, p. 148.

52 On 1 June 1993 Capitol Castings distributed among its employees a request asking them to submit letters detailing their concerns to the MCAPCD hearing board. The letter included a fact sheet produced by the company and a list of points employees might want to make in their letter. Letter from Charles P. Stanford, Jr., V.P. \& General Manager, Chandler Grinding Media Division, addressed to "Dear Valued Employee," 1 June 1993. 
1992 I got married. Together the three of us have a good life together and only dream of more. ${ }^{53}$

A sales administration supervisor in Capitol Castings offered the following assessment of his company's predicament: "We produce wear-resistant steel castings for the mining industry. Our market is very sensitive to price and our competition is fierce." 54 Additional letters and presentations were offered by union representatives, business associates, suppliers of the company, and the Arizona Association of Industries.

The hearing board granted Capitol Castings a one-year conditional permit on 21 June 1993. The permit allowed Capitol to operate without major restrictions but required extensive testing to quantify the emissions and reduction of any excess emissions identified through the testing. In addition, Capitol Castings was instructed to retain an odor expert and "submit a report to the Division on the measures it proposes to take to reduce any odors from its facility, identified as a source of complaints." 55 Testing conducted under the conditional permit was to be directed at the resolution of the long-standing dispute regarding the company's compliance with limits on particulates and VOC emissions. In addition, the company was required to produce estimates of its emission of a long list of suspected hazardous pollutants. The company retained the same odor expert who consulted for PSC in the Berkeley case. The expert who testified before the hearing board detected "phenol formaldehyde coming from Capitol Castings" but noted the presence of multiple other odor sources in the area. ${ }^{56}$ A first report issued by the odor consultant in August 1993 suggested that a change in the binders used by Capitol Castings might be sufficient to reduce odor complaints. The report asserted that carbon adsorption solutions, because of the hot Arizona climate, would be difficult to implement in this case. Thermal incineration was recognized as an effective solution, but the report pointed to drawbacks associated with its high cost. ${ }^{57}$

In March 1994 the hearing board held another public hearing in connection with the case. Capitol Castings reported that in accordance with the odor expert's suggestions, it had switched to a different binder and announced that it would install fans directed at diffusing and slowing the rate of emissions. Capitol Castings also relayed its consultant's assessment that the odor did

53 Employee letter to the MCAPCD Hearing Board, 10 June 1993.

54 Letter to MCAPCD Hearing Board, 2 June 1993.

55 Conditional Permit, appendix A, Issued to Capitol Castings, Inc., Tempe Foundry Division, 21 June 1993.

56 Reporter's transcript of Public Hearing on 4 June 1993, pp. 80, 81.

57 Odor Science and Engineering, Report to Capitol Castings, Inc., on Odor Investigation at Capitol Castings' Tempe Facility. OS\&E Project No. 0322-1-01, 16 Aug. 1993, p. 3-1. 
not constitute a health risk. When CAN members disputed the basis for this finding, the MCAPCD compliance supervisor candidly acknowledged the limited protections offered by the district's regulations with the statement, "if we say these emission levels are acceptable, we are talking about acceptable within our regulations. We don't have something that says that this is the health base level or this is how much concentration is considered helpful or not. It is a numerical emission limitation for some kind of work practice standard." An attorney for the MCAPCD concurred, adding that "right now there is no numerical limit which can be enforced for many hazardous air pollutants." 58

Only five representatives from CAN were present at the March 1994 meeting, and their testimony revealed growing diffculties in the group's organizational momentum. Central members, including the person who began the process in 1988, had moved out of the neighborhood. 59 Those left behind were feeling increasingly demoralized. A woman who was central to CAN's activities during the previous year offered the following description of her diminishing resolve:

I along with my fellow neighbors, have spent much more than enough time to play this game of charade during this entire permit process. Just waiting to see how long we can hang in there. We have called and called complaining to Capitol Castings and/or the County only to receive either no response ... to I don't smell anything or it can't be coming from us. . . . I have not called every time I have encountered the fumes, frankly, I am not going to take away that time from my family any longer. If it is convenient for me to call I'll call, I don't see any more official complaining making any difference. ${ }^{60}$

The fans were tested and discarded during the summer of 1994, and Capitol Castings undertook additional odor control experiments. A new permit application is still pending, and negotiations continue over the level of VOCs emitted by the company and appropriate measures for their control. The MCAPCD has become increasingly aggressive in its approach to the problem and, if nonnuisance-related regulatory violations can be documented, may well insist on comprehensive abatement action. Nevertheless, the agency remains unwilling to implement its reactive odor control mandate. Throughout the summer of 1994 local residents have continued to complain.

58 Maricopa County Air Pollution Control Hearing-Capitol Castings, Inc., 10 March 1994, Reporter's Transcript of Proceedings, pp. 58, 60.

59 In interviews, those who moved out of the neighborhood during the past year said that the emissions were a contributing but not the sole reason for their decision.

60 Written comments prepared in advance of the 4 June hearing. Oral testimony actually delivered by that person during the hearing followed the general gist of the quoted statement. 


\section{Discussion}

Although the Wells, Capitol Castings, and Pacific Steel disputes were virtually concurrent, none of the three neighborhood antipollution groups was aware of the others' efforts. Nor is there any evidence of communication among the three agencies overseeing these cases. Although the same industrial process and odorous emissions were at the center of all three disputes, in accordance with the fundamental precepts of reactive regulation each case was evaluated as a unique and distinct controversy. For each foundry, complainants and agencies needed to establish that emissions from specific facilities violated reasonableness standards within each relevant community. Across the United States there are thousands of foundries like the three described here (Foundry Management \& Technology 1992). Where local populations are affected by the fumes emitted by these plants, each neighborhood must make its own case for intervention.

Under the proactive regulatory model rejected by the EPA, pollutants of this sort would be uniformly controlled through technology or emission standards. Instead, potentially toxic, uncontrolled foundry fumes remain subject to reactive structures under rationales of diversity in local environmental choice.

Deference to local choice does not, in and of itself, preclude the possibility that most or all foundry neighbors would opt for cleaner air. But the economic benefits implicit to reactive structures are incompatible with conditions of frequent, successful mobilization. In a hypothetical world where most communities demanded and achieved a similarly high standard of abatement, aggregate pollution control costs (including the costs of uncertainty, expensive retrofitting, complaint handling, and litigation) are likely to be higher than those associated with uniform proactive standards.

While this study does not address the likelihood of local protest against foundry fumes, the history of the disputes suggests that the voicing of claims is only the first step in a long and uncertain quest for pollution remedies. All three foundry disputes were the result of persistent and unambiguous complaints against local environmental conditions. In all three cases, pollution abatement was averted or delayed through judicial or regulatory formulations of relevant thresholds and norms. While judicial responses in the Berkeley and Skokie disputes specifically articulated these norms and the distributions they justified, the regulatory policies of the BAAQMD and MCAPCD seemed intent on avoiding such moments of explicit allocation.

The legitimacy of courts, like that of all triadic conflict resolution structures, depends on their ability to bridge coercion with consent (Shapiro 1981). In the context of air pollution nuisance adjudication, this resolution has been pursued through a priori 
assumptions of consent to local environmental conditions and distinctions between prevailing values and the sensitivities underpinning rejected claims. Judicial decisions in the Wells and PSC cases followed along this line when they invoked the nature of the locale, the mildness of the odor, and the negative impact of organization on the authenticity of claims.

Unlike courts, agencies can often deflect and avoid hard choices, and it is toward this goal that reactive odor enforcement policies appear to be largely directed. Without engaging in direct balancing between the interests of neighbors and industry, BAAQMD policies dismiss most odor complaints as insufficient indicators of local community standards. These standards are defined by the BAAQMD through evidentiary requirements of five complaint confirmations in a day or the detection of an odor following a fourfold dilution of an air sample. Complainants who fail to meet these conditions are left, much like losing nuisance plaintiffs in court, with the message that they had failed to establish a valid claim. But unlike the finality of the loss that judges impose, reactive air pollution administration rarely forecloses the possibility of future relief. This remains true even though, as in Tempe, the agency has been extremely reluctant to undertake comprehensive anti-odor measures.

As indicated by the activist stance of the BAAQMD hearing board and the Illinois Pollution Control Board, reactive air pollution control institutions are not always unsympathetic to the complaints of citizens. Nor, as the ultimate resolution in the PSC case demonstrates, are all demands for odor pollution abatement doomed to fail. Occasional reactive interventions accord with the logic of community and environmental diversity and are probably crucial to the legitimacy of such structures. It is only when such interventions become routine that the link between reactive environmental law and the status quo is severed and the economic logic of such structures disappears. There is little in the stories told here to suggest the likelihood of such a transformation even under conditions of persistent challenge to ostensibly rebuttable presumptions of community tolerance.

\section{Conclusion}

The relationship between community choice and local environmental conditions has increasingly become an object of both political controversy and academic attention. Two related developments are at the center of these debates. The first is the outrage expressed by poor and minority communities against the disproportionate environmental burdens industrial facilities impose on their locale (United Church of Christ Commission for Racial Justice 1987; Bullard 1990; Mohai \& Bryant 1992; Cole 1992); the second is the gridlock created by local opposition to 
the siting of a growing spectrum of locally unwanted land uses (Popper 1991; Mazmanian \& Morell 1990; Brion 1991). In combination, the two phenomena have challenged longstanding presumptions of differences in local environmental preferences and priorities and have suggested the inadequacy of regulatory models premised on the presence of such diversities.

The regulation of air pollution under reactive nuisance structures is a prime example of the place of voluntary diversity suppositions in present environmental policies. The difficulties courts and agencies have encountered in the implementation of these structures illuminates fundamental contradictions in the basic commitments of reactive allocative institutions. While it is the theoretical possibility of complaints and the formal availability of complaint channels that grounds the legitimacy of such reactive systems, it is the expectation that complaints will rarely materialize that anchors their rationale. Reactive nuisance enforcement, like all conflict resolution models of regulation, is founded on the anticipation that complaints will be exceptional occurrences within a normally harmonious coexistence between industrial, municipal, and residential neighbors. When these expectations are frustrated and variations in pollution tolerance do not materialize, allocation mechanisms that depend on such differentiations can function only through formal constructions of local choice. In the context of air pollution nuisance adjudication and regulation, these constructions have been grounded in manufactured conceptions of communities harboring shared values regarding environmental trade-offs and priorities. While quiescence within such communities was invariably interpreted as consent, protest would at best become an occasion for explicit balancing of the interests involved.

Both the environmental justice movement and the NIMBY syndrome have drastically challenged presumptions of chosen environmental diversity and highlighted problems of both equity and efficiency in current systems of environmental burden distribution. With growing convergence in the environmental priorities articulated by groups in all social strata, once-hidden utilitarian allocations are increasingly uncovered. Because such explicit allocations conflict with commitments to the well-being of all individuals, they can undermine bonds of social commitment and expose moral contradictions (Calabresi \& Bobbit 1978). Formal deference to local initiative and the legal neutrality of reactive structures long diffused these tensions by relieving governmental institutions of responsibility for distributional outcomes. The current crisis in environmental burden allocation suggests a growing need to confront personal and collective costs long hidden through constructions of community choice. 


\section{References}

Bachrach, Peter, \& Morton S. Baratz (1962) "The Two Faces of Power," 56 American Political Science Rev. 947.

Bardach, Eugene, \& Robert A. Kagan (1982) Going by the Book: The Problem of Regulatory Unreasonableness. Philadelphia: Temple Univ. Press.

Barger, Brian (1993) "People Say Procter \& Gamble's Pulp Mill Makes Them Sick," Cable News Network Transcript \#388-5 (April 20).

Bendix, Selina (1990) "Toxicological Analysis of Chemicals Used at Pacific Steel Casting Company." Report prepared for City of Berkeley Department of Health \& Human Services, November 1990.

Best, Arthur, \& Alan R. Andreasen (1977) "Consumer Response to Unsatisfactory Purchases: A Survey of Perceiving Defects, Voicing Complaints, and Obtaining Redress," 11 Law $\mathcal{E}^{2}$ Society Rev. 701.

Boatwright, Dan (1992) "Cities Should Consider Air Quality in Planning," West County Times, 14 May, p. 11A.

Black, Henry Campbell (1990) Black's Law Dictionary. St. Paul, MN: West Publishing Co.

Black, Donald J. (1973) "The Mobilization of Law," 2 J. of Legal Studies 125.

Bone, Robert G. (1986) "Normative Theory and Legal Doctrine in American Nuisance Law: 1850-1920," 59 Southern California Law Rev. 1101.

Brion; Denis.J. (1991) Essential Industry and the NIMBY Phenomenon. New York: Quorum Books.

Bryner, Gary C. (1993) Blue Skies, Green Politics: The Clean Air Act of 1990. Washington, DC: CQ Press.

Bullard, Robert D. (1990) Dumping in Dixie: Race, Class, and Environmental Quality. Boulder, CO: Westview Press.

Bumiller, Kristen (1988) The Civil Rights Society: The Social Construction of Victims. Baltimore: Johns Hopkins Univ. Press.

Calabresi, Guido, \& Philip Bobbit (1978) Tragic Choices. New York: Norton.

Chan, Christina S. (1992) "Pacific Steel Casting Becomes Better Neighbor: Solution to Plant Odor Emission Problem," 120 Foundry Management $\mathcal{E}$ Technology 26 (Aug.).

Chard, Leslie F., III. (1991) Comment: "The 1990 Clean Air Act Amendments: Section 112 Comes of Age," 59 Univ. of Cincinnati Law Rev. 1253.

Chaset, Laurence G. (1987) "Enforcement.Mechanisms for Resolving Community Odor Problems: A Legal Viewpoint.". Presented at 80th Annual Meeting of Air Pollution Control Association, New York (21-26 June).

Cole, Luke W. (1992) "Empowerment as the Key to Environmental Protection: The Need for Environmental Poverty Law," 19 Ecology Law Q. 619.

Copley International Corporation (CIC) (1970) "National Survey of the Odor Problem: Phase I of a Study of the Social and Economic Impact of Odors." Prepared for National Air Pollution Control Administration. Springfield, VA: Clearinghouse for Federal Scientific \& Technical Information. (1971) "A Study of the Social and Economic Impact of Odors: Phase II." Final Report Prepared for the Environmental Protection Agency. Springfield, VA: National Technical Information Service, U.S. Department of Commerce.

(1973) "A Study of the Social and Economic Impact of Odors: Phase III, Development and Evaluation of a Model Odor Control Ordinance." Prepared for Environmental Protection Agency. Washington, DC: National Technical Information Service, U.S. Department of Commerce.

Crank, John P. (1994) "Watchman and Community: Myth and Institutionalization in Policing," 28 Law $\mathcal{E}$ Society Rev. 325.

Crenson, Matthew A. (1971) The Un-Politics of Air Pollution: A Study of Non-Decisionmaking in the Cities. Baltimore: Johns Hopkins Univ. Press. 
Crowe, Patricia Ward (1978) "Complainant Reactions to the Massachusetts Commission against Discrimination," 12 Law E Society Rev. 217.

Dahl, Robert A. (1961) Who Governs? Democracy and Power in an American City. New Haven, CT: Yale Univ. Press.

Dwyer, John P. (1990) "The Pathology of Symbolic Legislation," 17 Ecology Law Q. 233.

Eads, George (1985) "The Confusion of Goals and Instruments: The Explicit Consideration of Cost in Setting National Ambient Air Quality Standards," in M. Gibson, ed., To Breathe Freely: Risk, Consent, and Air. Totowa, NJ: Rowman \& Allanheld.

Edelen, Earl W., \& Howard L. Clark (1951) "Odor Control in Los Angeles County," 1 (3) Air Repair 1.

Ellickson, Robert C. (1973) "Alternatives to Zoning: Covenants, Nuisance Rules, and Fines as Land Use Controls," 40 Univ. of Chicago Law Rev. 681.

Epstein, Richard A. (1979) "Nuisance Law: Corrective Justice and Its Utilitarian Constraints," $8 \mathrm{~J}$. of Legal Studies 49.

Felstiner, William L. F., Richard L. Abel, \& Austin Sarat (1980-81) "The Emergence and Transformation of Disputes: Naming, Blaming, Claiming ...., 15 Law E Society Rev. 631.

Foundry Management \& Technology (1992) "Metal Casting Industry Census Guide." Cleveland: Penton Publishing.

Goldberg, Alan Jay (1988) "Toward Sensible Regulation of Hazardous Air Pollutants under Section 112 of the Clean Air Act," 63 New York Univ. Law Rev. 612.

Graham, John D. (1985) "The Failure of Agency-Forcing: The Regulation of Airborne Carcinogens under Section 112 of the Clean Air Act," 1985 Duke Law J. 100.

Grinder, R. Kale (1980) "The Battle for Clean Air: The Smoke Problem in Post-Civil War America," in M. V. Melosi, ed., Pollution and Reform in American Cities, 1870-1930. Austin: Univ. of Texas Press.

Gruber, Charles W. (1957) "Odor Pollution Problems from the Control Officials' Viewpoint," $7 \mathrm{~J}$. of the Air Pollution Control Association 56.

Hawkins, Keith (1984) Environment and Enforcement: Regulation and the Social Definition of Pollution. Oxford: Clarendon Press.

Henderson, James A., Jr., \& Richard N. Pearson (1978) "Implementing Federal Environmental Policies: The Limits of Aspirational Commands," 78 Columbia Law Rev. 1429.

Hoye, David (1993) "Air of Discontent: Residents Say Odors Fouling Neighborhood Near Foundry," Phoenix Gazette, 31 March, Metro sec., p. B1.

Hubert, Cynthia (1993) "Fuming Residents Say Industrial Odors Are Ruining Rocklin," Sacramento Bee, 23 Oct., sec. 1 (Metro), p. B1.

Jones, Charles O. (1975) Clean Air: The Policies and Politics of Pollution Control. Pittsburgh: Univ. of Pittsburgh Press.

Juergensmeyer, Julian Conrad (1967) "Control of Air Pollution through the Assertion of Private Rights," 1967 Duke Law J. 1126

Kagan, Robert A. (1994) "Regulatory Enforcement," in D. H. Rosenbloom \& R. D. Schwartz, eds., Handbook of Regulation and Administrative Law. New York: Marcel Dekker, Inc.

Klockars, Carl B. (1991) "The Rhetoric of Community Policing," in C. B. Klockars \& S. D. Mastrofski, eds., Thinking about Policing. 2d ed. New York: McGraw-Hill.

Krier, James E., \& Clayton P. Gillette (1985) "The Un-Easy Case for Technological Optimism," 84 Michigan Law Rev. 405.

Krier, James E., \& Edmund Ursin (1977) Pollution and Policy: A Case Essay on California and Federal Experience with Motor Vehicle Air Pollution, 1940-1975. Berkeley: Univ. of California Press. 
Kurtz, Paul M. (1976) "Nineteenth Century Anti-Entrepreneurial Nuisance Injunctions-Avoiding the Chancellor," 17 William E Mary Law Rev. 621.

Laitos, Jan G. (1975) "The Social and Economic Roots of Judge-Made Air Pollution Policy in Wisconsin," 58 Marquette Law Rev. 465.

La Pierre, D. Bruce (1977) "Technology-Forcing and Federal Environmental Protection Statutes," 62 Iowa Law Rev. 771.

Laxson, Toni K (1993) "Plant's Neighbors Report Foul Odors: HazardousWaste Firm in East Texas Denies That Smell Is Nuisance," Dallas Morning News, 28 July, News sec., p. 30A.

Lazarus, Richard J. (1993) "Pursuing 'Environmental Justice': The Distributional Effects of Environmental Protection," 87 Northwestern Univ. Law Rev. 787.

Lee, Steven H. (1993) "Tension in the Air: Battle over Feedlot's Odor Puts Dairy Industry on Trial," Dallas Morning News, 30 May, Business sec., p. $1 \mathrm{H}$.

Lewin, Jeff L. (1990) "Boomer and the American Law of Nuisance: Past, Present, and Future," 54 Albany Law Rev. 189.

Lindvall, Thomas, \& Edward P. Radford, eds. (1973) "Measurement of Annoyance Due to Exposure to Environmental Factors," 6 Environmental Research 1.

Lukes, Steven (1974) Power: A Radical View. London: Macmillan.

Manning, Kay (1993) "Chemical Warfare; Winona Wants Waste Plant Shut Down, Citing Health Ills," Dallas Morning News, 7 March, Texas \& Southwest sec., p. 47A.

Mayhew, Leon H. (1968) Law and Equal Opportunity: A Study of the Massachusetts Commission against Discrimination. Cambridge, MA: Harvard Univ. Press.

Mazmanian, Daniel, \& David Morell (1990) "The 'NIMBY' Syndrome: Facility Siting and the Failure of Democratic Discourse," in N. J. Vig \& M. E. Kraft, eds., Environmental Policy in the 1990s: Toward a New Agenda. Washington, DC: CQ Press.

Mohai, Paul, \& Bunyan Bryant (1992) "Environmental Racism: Reviewing the Evidence," in P. Bryant, B. Bunyan, \& P. Mohai, eds., Race and the Incidence of Environmental Hazards: A Time for Discourse. Boulder, CO: Westview Press.

Nader, Laura (1980a) "Alternatives to the American Judicial System," in Nader $1980 \mathrm{~b}$. ed. (1980b) No Access to Law: Alternatives to the American Judicial System. New York: Academic Press.

Nader, Laura, \& Christopher Shugart (1980) "Old Solutions for Old Problems," in Nader 1980b.

National Research Council Committee on Odors from Stationary \& Mobile Sources (1979) Odors from Stationary and Mobile Sources. Washington, DC: National Academy of Sciences.

Nelson, Bryce (1967) “Air Pollution: The 'Feds' Move to Abate Idaho Pulp Mill Stench," 157 Science 1018.

Olson, Mancur (1971) The Logic of Collective Action. Cambridge, MA: Harvard Univ. Press.

Petriko, Bryan K. (1993) "Conducting an Air Emissions Inventory," 121 Foundry Management EO Technology 34 (Nov.).

Pollack, Lawrence W. (1968) "Legal Boundaries of Air Pollution Control-State and Local Legislative Purpose and Techniques," 33 Law EJ Contemporary Problems 331 (Spring).

Polsby, Nelson W. (1980) Community Power and Political Theory. 2d enlarged ed. New Haven, CT: Yale Univ. Press.

Popper, Frank J. (1991) "LULUs and Their Blockage: The Nature of the Problem, the Outline of the Solutions," in J. DiMento \& L. Graymer, eds., Confronting Regional Challenges. Cambridge, MA: Lincoln Institute of Land Policy. 
Reiss, Albert J., Jr. (1971) The Police and the Public. New Haven, CT: Yale Univ. Press.

Reitze, Arnold W., Jr. (1991) "A Century of Air Pollution Control Law: What's Worked; What's Failed; What Might Work," 21 Environmental Law 1549.

Robertson, Peter D., \& Timothy A. Vanderver, Jr. (1992) "Title III-Air Toxics," in T. A. Vanderver, Jr., ed., Clean Air Law and Regulation. Washington, DC: BNA.

Rodgers, William H., Jr. (1986) Environmental Law. St. Paul: West Publishing Co.

Rollenhagen, Mark (1994) "Lawsuit Seeks to Clear the Air; Ravenna Families Complain of Odor," Cleveland Plain Dealer, 6 May, Metro sec.; p. 1 B.

Scheinman, Kate (1990) "The Battle for West Berkeley," East Bay Guardian, Sept., p. 29.

Schoenbrod, David (1983) "Goals Statutes or Rules Statutes: The Case of the Clean Air Act," 30 UCLA Law Rev. 740.

Scholz, John T., \& Feng Heng Wei (1986) "Regulatory Enforcement in a Federalist System," 80 American Political Science Rev. 1249.

Schroeder, Christopher (1983) "Foreword: A Decade of Change in Regulating the Chemical Industry," 46 Law $\mathcal{E}$ Contemporary Problems 1 (Summer).

Schroeder, Christopher H. (1986) "Rights against Risks," 86 Columbia Law Rev. 495.

Shapiro, Martin (1981) Courts: A Comparative and Political Analysis. Chicago: Univ. of Chicago Press.

Shusterman, Dennis (1992) "Critical Review: The Health Significance of Environmental Odor Pollution," 47 Archives of Environmental Health 76.

Stern, Arthur C. (1957) "Summary of the Conference on Odor Control," $7 \mathrm{~J}$. of the Air Pollution Control Association 53.

Sunstein, Cass R. (1990) After the Rights Revolution: Reconceiving the Regulatory State. Cambridge, MA: Harvard Univ. Press.

Texas Air Control Board (1993) "Survey of State, Regional and Local Nuisance Odor Policies." Legal Division (25 Feb.). Austin: Texas Air Control Board.

United Church of Christ Commission for Racial Justice (1987) "Toxic Wastes and Race in the United States: A National Report on the Racial and Socioeconomic Characteristics of Communities with Hazardous Waste Sites." New York: Public Data Access.

U.S. Environmental Protection Agency (1980) "Regulatory Options for the Control of Odors." EPA Report No. 450/5-80-003. Research Triangle Park, North Carolina.

(1992) "Reference Guide to Odor Thresholds for Hazardous Air Pollutants Listed in the Clean Air Act Amendments of 1990." Washington, DC: U.S. Environmental Protection Agency.

Yale Law Journal (1979) Note: "Forcing Technology: The Clean Air Act Experience," 88 Yale Law J. 1713.

Yngvesson, Barbara (1993) Virtuous Citizens, Disruptive Subjects: Order and Complaint in a New England Court. New York: Routledge.

Yozwiak, Steve (1993) "Nasty Odor Keeps Area Homes Shut; Tempe Residents Blame Foundry," Arizona Republic, Valley \& State sec., 30 March, p. B1.

\section{Cases}

Bay Area Air Quality Management Dist. v. Pacific Steel Castings Co., BerkeleyAlbany Municipal Court, (1991) No. BCV0067442.

Processing \& Books, Inc. v. Illinois Pollution Control Bd., 28 Ill. App. 3d 115, 328 N.E. 2d 338 (1976).

Versailles Borough v. McKeesport Coal \& Coke Co., 83 Pittsburgh Legal Journal 379 (1935). 
Wells Mfg. Co. v. Pollution Control Bd., 48 Ill. App. 3d 337, 6 Ill. Dec. 497, 363 N.E. $2 d 26$ (1977).

Wells Mfg. Co. v. Pollution Control Bd., 73 Ill. 2d 226, Ill. Dec. 672, 383 N.E. 2d 148 (1978).

Wells Mfg. Co. v. EPA, 195 Ill. App. 3d 593, 142 Ill. Dec. 333, 552 N.E. 2d 1074 (1990).

\section{Statutes}

Ariz. Rev. Stat. Ann. sec. 49-471 (West 1988).

Air Quality Act of 1967, Pub. L. No. 90-148, 81 Stat. 485 (1967).

California Health \& Safety Code sec. 41700 (West 1990).

Clean Air Act Amendments, Pub. L. No. 91-604, 84 Stat. 1676 (1970).

Clean Air Act Amendments, Pub. L. No. 95-95, 91 Stat. 385 (1977).

Clean Air Act Amendments, Pub. L. No. 549, 104 Stat. 2399, $2531-74$ (1990).

Environmental Protection Act, Ill. Rev. Stat. ch. 111 1/2, II 1003.02, 1009(a), 1033(b) (Smith-Hurd 1988) (recodified at 415 Ill. Comp. Stat. Ann. II 5 / 9, 5/3, 5/33 (1993 \& Supp. 1994). 
Heinonline -- 28 Law \& Soc'y Rev. 10781994 